\title{
An Architectural Framework for Global Talent Management
}

Shad S. Morris

Brigham Young University, morris@byu.edu

Scott Snell

University of Virginia, snells@darden.virginia.edu

Ingmar Björkman

Aalto University, ingmar.bjorkman@aalto.fi

Follow this and additional works at: https://scholarsarchive.byu.edu/facpub

Part of the Human Resources Management Commons

\section{Original Publication Citation}

Morris, S., Snell, S., \& Björkman, I. (2016). An architectural framework for global talent management. Journal of International Business Studies, 47(6), 723-747.

\section{BYU ScholarsArchive Citation}

Morris, Shad S.; Snell, Scott; and Björkman, Ingmar, "An Architectural Framework for Global Talent Management" (2016). Faculty Publications. 1821.

https://scholarsarchive.byu.edu/facpub/1821 


\title{
An Architectural Framework for Global Talent Management
}

\author{
Shad Morris \\ Marriott School of Management \\ Brigham Young University \\ Provo, USA \\ morris@byu.edu \\ Scott Snell \\ Darden School of Business \\ University of Virginia \\ Charlottesville, USA \\ snells@darden.virginia.edu \\ Ingmar Björkman \\ Aalto University School of Business \\ Helsinki, FINLAND \\ Ingmar.bjorkman@aalto.fi
}

Final version published in The Journal of International Business Studies, 47(6), 723-747.

Running Title: An Architectural Framework for Global Talent Management

Keywords: knowledge-based view, HRM strategies, human capital, multinational corporations, talent management, organizational learning

Acknowledgements: We would like to thank our editor, Paula Caligiuri, and reviewers for insightful direction and comments guiding this paper through the review process. We would also like to thank faculty members at Copenhagen Business School and The Ohio State University for valuable comments and direction on this paper. 


\begin{abstract}
About the Authors
Shad Morris (Cornell University, Ph.D.) is the Georgia White Fellow and Assistant Professor of Organizational Leadership and Strategy at Brigham Young University's Marriott School of Management. His research addresses international business and strategic human resource management issues, concentrating particularly on how global firms innovate through people and knowledge. (Citizenship: USA)

Scott Snell (Michigan State University, Ph.D.) is Professor and Senior Associate Dean of Executive Education at the University of Virginia's Darden Graduate School of Business. His research focuses on strategic human resource management, human capital and talent management, as well as strategic capability and organizational learning. (Citizenship: USA)

Ingmar Björkman (Hanken School of Economics, Ph.D.) is Professor and Dean of Aalto University School of Business in Finland. His research interests focus on people management issues in multinational corporations and international mergers \& acquisitions. This is his $10^{\text {th }}$ article published in Journal of International Business Studies. (Citizenship: Finland)
\end{abstract}




\begin{abstract}
A unique characteristic of the multinational corporation is that it comprises a geographically dispersed and culturally differentiated workforce that embodies both firm-specific and locationspecific human capital. This paper takes an architectural approach to describe how different types of human capital develop from the individual level, to the unit level, and then to the firm level in order to build a talent portfolio for the multinational corporation. Depending on the company's strategy (multidomestic, meganational, transnational), different configurations of the talent portfolio tend to be emphasized and integrated to achieve competitive advantage. Implications for theory and practice are discussed and a research agenda is introduced.
\end{abstract}




\section{INTRODUCTION}

How and where do companies concentrate their talent investments in order to globally compete? Companies have addressed this question in a variety of ways, ranging from developing leaders in unlikely emerging markets to investing in new technologies for talent gap assessment (Stahl et al., 2012). However, in a postindustrial age, what drives talent decisions is the utilization of knowledge (Kogut \& Zander, 1993). Knowledge is embedded in people, and the question of how to globally develop and integrate strategic human capital proves to be of both practical and theoretical significance.

Scholars have recently begun studying the link between human capital and knowledgebased competitive advantage (Fey \& Furu, 2008; Hatch \& Dyer, 2004; Kumar, van Fenema, \& Von Glinow, 2005). However, there is a theoretical gap in the literature that may constrain further empirical progress in this area of research. Traditionally, the knowledge-based view (KBV) arguments about advantage have been considered mainly at the firm level, without addressing more microfoundational parts of the workforce as an input to strategy (Cappelli \& Keller, 2014; Foss \& Pedersen, 2004). Conversely, most research on human capital (and human resources, generally) tends to address the issue from an individual perspective and ties human capital to the firm by aggregating the individuals' human capital. Theoretical work about human capital at a more macro or strategic level is less developed (e.g., Campbell et al., 2012; Morris et al., 2012; Ployhart \& Moliterno, 2011), especially when we consider the scope and complexity of a multinational corporation's (MNC) global portfolio of talent.

Our purpose is to develop a framework that shows the overall architecture (or theoretical structure) of an MNC's global portfolio of human capital. We do this in order to address questions about how firms develop and leverage their talent to generate and integrate knowledge strategically. We define talent as people who make valuable contributions to organizational objectives (for example, high-level managers, high-potential individuals, and those with rare 
knowledge and skills) (Schuler, Jackson, \& Tarique, 2011; Scullion \& Collings, 2011; Vaiman et al., 2010). Hence, employees may be considered talent regardless of their position or location. Such a framework is intended to achieve three outcomes.

First, we use the framework to explore which types of human capital matter most in the context of a company's talent portfolio. We discuss four different types of human capital, using the economic notion of asset specificity (Riordan \& Williamson, 1985). Researchers have noted that assets are potentially more valuable as a source of advantage when they can't be easily transferred from one context to another. Within the MNC, there are two main contexts that determine the immobility of assets: (a) firm context (i.e., firm specificity) and (b) local market context (i.e., location specificity). On the one hand, firm-specific human capital is a more likely advantage for the firm because it is less transferrable and therefore more difficult for other firms to appropriate (Lepak \& Snell, 1999; Wright \& McMahan, 1992; see Mackey, Molloy, \& Morris, 2014 for exceptions). On the other hand, a critical source of strategic knowledge relates to the local context because it can be both a source of differentiation to the MNC locally and of knowledge generation globally (e.g., Caligiuri, Lazarova, \& Zehetbauer, 2004; Joshi, Labianca, \& Caligiuri, 2002; Reiche, Harzing, \& Kraimer, 2009). We will discuss how both firm specificity and location specificity influence competitiveness of the MNC.

Second, we use our framework to address questions related to degrees of analysis in talent management. Keeping with the microfoundations perspective of strategy, we examine the interplay of human capital at the individual, unit, and firm levels. Much of the literature on human capital emphasizes the individual level of analysis, while recognizing the more macro level implications (e.g., Becker, 1964). Recent work has focused on unpacking the phenomenon of macro human capital "emergence” (cf., Ployhart \& Moliterno, 2011). We build on this literature and extend it toward the firm-level view of MNCs. 
Third, we use our framework to examine how different types of human capital combine and interact with one another in the context of different global strategies. In particular, three different strategies_-multidomestic, meganational and transnational (Pucik, Evans, Bjorkman \& Morris, 2016) — are central to our analysis. ${ }^{1}$ These strategic approaches illustrate how companies can align their talent portfolios to support their particular needs for knowledge generation and integration. We build on work from international human resource (HR) scholars to discuss ways in which companies may draw upon HR management to design and encourage the appropriate human capital integrations and then to discuss how this plays out at the firm, unit, and individual levels (Lengnick-Hall \& Lengnick-Hall, 2006).

We use the term architecture to refer to this framework in order to clarify that the form a global talent portfolio takes has a direct impact on the way talent functions in generating and integrating knowledge aligned with strategy. Choices about this configuration represent an important facet of organizational design, but one for which there is very little research (cf., Morris \& Snell, 2011). Accordingly, in the discussion section, we provide a research agenda to help scholars assess a firm's human capital architecture for global talent management. Our intent is to provide a conceptual lens that encourages future scholarship and empirical research in a way that directly informs managerial practice.

\section{HUMAN CAPITAL IN THE GLOBAL CONTEXT}

As a starting point for theory, we recognize that human capital cannot be independent of individuals or the context in which it is formed. As shown in Figure 1, we lay out two dimensions of the human capital context that are unique to the $\mathrm{MNC}$, each reflecting the distinction between general and specific human capital (cf., Lepak \& Snell, 1999; Ployhart \&

\footnotetext{
${ }^{1}$ While Bartlett \& Ghoshal (1989) originally included the "international strategy", Harzing (2000) points out that this strategy is not legitimately a strategy.
} 
Moliterno, 2011). The first dimension refers to the degree of firm specificity of knowledge. Firm-specific human capital is developed and maintained internally by the firm itself. It is contextually embedded within the firm, reflecting knowledge relevant to a unique company culture, routine, and system, which knowledge is not potentially applicable across firms (cf., Becker, 1964).

[Insert Figure 1 about here]

The second dimension is the degree of location specificity (cf., Krupka, 2007). In the research on MNCs, location-specific human capital has been identified by scholars as a distinct form of knowledge that is relevant or applicable in a particular country (cf., Isobe, Makino, \& Montgomery, 2000; Rosenthal \& Strange, 2008). The local context represents the most salient factor (even over the regional context) in examining MNCs (Shenkar, 2004). In the case of location-specific human capital, the embedded contextual knowledge pertains to a particular geographic, cultural, political, or economic system rather than to a particular firm (Cantwell \& Mudambi, 2005; Inkpen, 1997; Schulz, 2001).

Putting the dimensions of firm specificity and location specificity side by side, we identify four critical types of human capital within the MNC: local, subsidiary, corporate, and international. Each of these types develops differently, is typically managed differently, and contributes differently to the overall strategic posture of the firm.

\section{Local Human Capital}

Local human capital represents knowledge, skills, abilities, and other attributes that reflect the location-specific experiences of employees in a particular country or market. Such knowledge includes an understanding of customer needs, cultural traditions, institutional 
barriers, and political processes that may differ across countries (Doz \& Santos, 1997). ${ }^{2}$ This knowledge is found within a firm's talent base as well as within the local market networks, associations, and organizations outside the firm.

Individual level. At an individual level, host-country nationals may be the most likely to develop local knowledge, but this comes from their familiarity with the host market, rather than solely their nationality or location (Caligiuri, 2013). From the firm's perspective, it can either acquire local human capital by hiring individuals who already have the experience the firm needs or allow the knowledge to develop internally. Individuals gain local human capital as they engage in meaningful interactions with local constituencies (Caligiuri, 2013). Companies may help individuals gain these experiences by encouraging employees to reach outside their offices to talk more with local clients. These experiences create tacit forms of knowledge that make individual employees strategically valuable to the firm and irreplaceable by routines, processes, or systems.

However, firms and units with high levels of local human capital embedded within the routines, processes, and systems may be more effective at developing local human capital at the individual level. Because of its contextually unique and often unspoken characteristics, local human capital is not easily transferable to other country contexts. However, it is potentially transferable to other firms within the same locale. For that reason, firms that are new entrants into a region are typically very interested in acquiring or developing local human capital because it provides a foundation for doing business there. Firms frequently lament that their investments in local human capital are negated when other firms poach talent in the area. In addition to the direct cost of human capital loss, a firm's competitive potential can also be affected. A new

\footnotetext{
${ }^{2}$ While countries will vary in the value of their different contexts for the larger MNC, we argue that local human capital, in general, provides different enough contexts across borders to offer new insights for the MNC.
} 
firm's capacity to acquire local human capital reduces the entry barriers to new markets and decreases the competitive edge of incumbent firms.

Unit level. Unit-level local human capital reflects the aggregated knowledge and experience that emerge among individuals as they interact with one another and with people in the local environment. This collective asset can be influenced by both individual- and firm-level forms of human capital. For example, MNCs with strong levels of local human capital embedded across the organization may push local units to better understand their local environment.

In fact, while individuals can possess human capital, it is often developed collectivelyembedded within a social network and difficult to disaggregate back to the individual level. As a socially embedded resource, unit-level local human capital may not be interchangeable with individual-level human capital (Ployhart \& Moliterno, 2011). For example, Groysberg, Lee, and Nanda (2008) found that high-level talent hired by competing firms have struggled to apply their human capital in a new setting. One explanation is that some of their experience is embedded in a collective unit- or firm-level context that becomes difficult to transfer from one context to the next (Somaya \& Williamson, 2008).

The process of combining experience as well as acting together in the local context helps both to refine unit-level human capital and to create a broader, collective, cospecialized asset for the MNC (Teece, 1986). Managers frequently refer to their "human capital" in a country and conceive of that capital more broadly than the mere sum of knowledge and experience of individual employees. Human capital is a construct that transcends the individuals and, in this sense, represents a key inflection point between individual and organizational learning. Any individual may have partial or unique knowledge, unique to his or her experience. But when combined with the knowledge of others in the unit, the aggregated knowledge may represent a far more robust, socially complex, and path-dependent form of human capital (cf., Kozlowski \& Klein, 2000). Hence, local human capital at the unit level is neither independent of individuals 
nor the context in which it is embedded. Instead, it is collectively held by a unit and its employees.

Firm level. If we expand our perspective to the firm level, we can recognize that the global talent portfolio of the MNC comprises various stocks of local human capital in different areas of the world. The degree of variety at the overall portfolio level represents an important strategic choice for firms, since there are clear benefits and costs inherent in this decision.

On the one hand, both the resource-based view and the knowledge-based view of firms emphasize the importance of knowledge variation as a foundation for organizational learning (Almeida, Song, \& Grant, 2002). The extent of local human capital in the firm's overall talent portfolio represents numerous points of connection with and learning about the different local environments in which the MNC operates. Similar to Conant and Ashby's (1970) notion of requisite variety, the local human capital represents the complex and varied stocks of knowledge that serve as a catalyst for knowledge generation.

On the other hand, heterogeneity brings with it challenges of control and coordination. Firms will sometimes make difficult tradeoffs between the degree of heterogeneity and homogeneity they seek at this level. For example, Andersson, Björkman, and Forsgren (2005) found that firms generally use expatriates and other headquarters personnel in key positions to maintain more direct control in an international location. This practice may constrain the local integration of units and individuals required for knowledge creation. The challenge for firms is to balance the advantages of local autonomy, differentiation, and heterogeneity against the needs for control, consistency, and global integration. Hence, we propose the following:

P1: Developing local human capital helps a firm interact with local clients and governments.

\section{Subsidiary Human Capital}


At the nexus of location-specific and firm-specific knowledge, subsidiary human capital represents knowledge relevant to the company in a specific country context. For example, when companies adapt their practices for the needs of a local market, they are creating the basis for generating subsidiary human capital (cf., Reiche et al., 2009). Such forms of human capital help to adapt knowledge for the local environment in ways that both support the goals of the firm and provide new insights to drive innovation.

Individual level. At the individual level, subsidiary human capital is the personalized combination of firm and local experience. It may be both unstated and stated because it is developed through an iterative process that occurs "bottom-up" as individuals reconcile local knowledge against firm-specific requirements and that occurs "top-down" as individuals adapt firm-specific knowledge to their local environment. Also, subsidiary human capital does not supplant or replace local human capital. They are qualitatively different, and they coexist as complementary assets.

This view of subsidiary human capital is in line with the work of Reiche, Harzing, and Kraimer (2009), who argue that knowledge from international assignees can be more effectively leveraged when it is developed through relationships embedded in both their home and host countries. In this regard, individual-level subsidiary human capital is influenced by unit and firm levels of firm-specific knowledge, combined with their individual knowledge of the market. The result for individuals is a potentially proprietary asset that provides both competitive differentiation and local adaptation. From the individuals' view, this asset may simultaneously increase their value to the organization and decrease the likelihood that they will (or can) transfer their experience to other firms. In this sense, subsidiary human capital acts as an isolating mechanism for the firm (Hatch \& Dyer, 2004), thereby restricting employee mobility externally.

The upshot is that converting location- and firm-specific human capital into subsidiary human capital takes place within the organization's social context, and, as a result, it frequently 
gathers at the unit level. Individuals benefit from the process recursively, because they are better able to blend firm and local experiences. However, shared experience is a byproduct of the knowledge-combination process. Repatriation programs, for example, when done effectively, establish the basis for a shared understanding that benefits both the firm and the individuals (Lazarova \& Tarique, 2005).

Unit level. When local knowledge is exchanged and combined among individuals with firm-specific knowledge, it becomes something that is both unique to the unit and less transferable to other firms. At the same time, if subsidiary knowledge is an important component to the firm, this higher level of subsidiary human capital will positively influence the development of subsidiary human capital at the unit level. For example, local sales and marketing units will improve their market share if they can effectively integrate their knowledge of the local client base and government regulations with their knowledge of all the firm's products and services (e.g., Schuiling \& Kapferer, 2004).

As a result, subsidiary human capital at the unit level is one of the strongest sources of competitive advantage for firms (Foss \& Pedersen, 2004). As noted above, this collective knowledge — or understanding — represents an asset that has been "transformed" and cannot be (fully) divided up again. When firm-specific resources shape collective knowledge — such as practices, norms, data, and the like - the knowledge becomes further embedded in the unit. Experiences, databases, communities of practice, after-action reviews, and so on are all methods for embedding subsidiary human capital in the unit. These methods highlight the interplay of the individuals' knowledge with social relationships, and that interchange enhances and complements both the human capital and organizational assets within the subsidiary.

Firm level. Just as with local human capital, MNCs make strategic decisions about how they manage subsidiary human capital for the overall talent portfolio. There is the question of degree: How much knowledge remains unique to the local units? And, therefore, how much 
heterogeneity is desired in the overall system? Firms may choose to allow some subsidiaries to develop their own talent pools, work methods, and opportunities for localized cultures, processes, and the like, while placing constraints on other subsidiaries. These localization strategies potentially allow for more creativity, customization, and innovation across the firm as a whole, generating new best practices that other units may adopt or adapt to solve their own problems or capture opportunities (cf., Bartlett \& Ghoshall, 1989). ${ }^{3}$

However, unlike the situation with local human capital, firm-level decisions about subsidiary human capital must consider their human capital's degree of firm specificity as well. On the one hand, some firm-specific human capital may apply exclusively within a single subsidiary: for example, experience in adapting a firm's unique processes for a particular location. On the other hand, some firm-specific knowledge from the subsidiary may transfer to others in the company as whole. The challenge for firms in this particular area is that the firmspecific aspect of the human capital is inseparable from the location-specific aspect. The translation process that needs to occur to make unique knowledge transferable globally often dilutes the firm-specific aspect of the human capital as well. The goal for the MNC in this context is to maximize local adaptation and global integration.

The paradox of integrating these unit-level forms of human capital frequently takes the form of (a) global policies and (b) local practices. The result is a set of processes that are customized to a subsidiary and a market. From resource and knowledge-based perspectives, the extent of subsidiary human capital in the firm's overall talent portfolio represents an integrated network of semiautonomous units that possess knowledge unique to the firm and different from that of competitors in the local market but adapted so they can maintain their local relevance.

\footnotetext{
${ }^{3}$ For HR practitioners in MNCs, "localization" may also refer to the employment practice of basing compensation on local conditions. For this discussion, we refer strictly to the academic literature on localization as a means to replace expatriates with local managers.
} 
This combined location and firm specificity make the special case for the MNC. If all knowledge elements existed everywhere, the knowledge of a "local" company and of a "global" company would be the same (Doz et al., 2001). Hence, we propose the following:

P2: Developing subsidiary human capital helps to develop products, services, and practices that are unique to both the firm and the countries in which it operates.

\section{Corporate Human Capital}

Corporate human capital is composed of firm-specific knowledge, skills, abilities, and other attributes whose value transcends any one particular location. Despite the connotation of the term "corporate" as synonymous with "headquarters," we view this type of human capital as that which is collectively shared within the MNC (cf., Latin, corpus, "united body, collection"). We not only conceive of corporate human capital as a top-down exposition of the firm's way of doing business, but we also view it as a bottom-up derivation of collective knowledge and experience that is applicable to the firm as a whole. When such derivation occurs, there are substantial opportunities for economies of scope in which learning investments from one part of the MNC are applicable in another. This opportunity for knowledge transfer also highlights a potential advantage of the MNC as an organizational form - to leverage and transfer learning more efficiently than the market alternative (Almeida, Song, \& Grant, 2002).

Individual level. Individuals acquire and develop corporate human capital from knowledge embedded within social and organizational contexts. In other words, corporate human capital not only emerges from individual to firm levels, but it also flows down from firm to individual. Without clear directives, distant subsidiary employees often struggle to gain corporate knowledge and often feel conflicted in reconciling corporate knowledge with local experience.

As individuals rotate across international locations, they may also develop corporate human capital inferentially because they accumulate experience iteratively and recognize which 
knowledge sets are generalizable to other locations. This type of corporate human capital often takes the form of specific guidelines for action rather than policies or procedures handed down by executive command. Leadership-development programs within MNCs are often explicitly designed to achieve this kind of corporate human capital synthesis (cf., Caligiuri \& Lazarova, 2001). Rather than dictating protocols top-down, leadership-rotational programs attempt to develop corporate human capital bottom-up. The advantage for the firm is that the derived corporate human capital is both informed by local experience and relevant to global concerns. Even though the uniqueness of location-specific knowledge may be lost, the elements that are generalizable are more likely to be firm specific.

In other instances, corporate human capital is developed as individuals contextualize best practice by synthesizing it with knowledge of firm-specific methods. For example, transferable expertise (for example, engineering) may be augmented by the specific ways the MNC uses the expertise.

Unit level. Similar to the subsidiary human capital discussed earlier, the emergence of corporate human capital at the unit level occurs in a social context as interdependent individuals exchange their unique experiences against knowledge base of the whole. However, unlike subsidiary human capital, the emergence process of corporate human capital does not need to be restricted to a particular region. In this case, the unit of shared experience could also include global functions, business units, leadership teams, or other MNC entities.

Bottom-up, the emergence of corporate human capital within these units occurs through a process of deriving knowledge from members' experiences that is broadly applicable across the MNC. Top-down, the process occurs by testing espoused knowledge from headquarters (frequently informed by best practice) against the realities of the units to ascertain which elements are indeed generalizable. 
Ironically, there are times when the headquarter's espoused knowledge may not meet the criteria of corporate human capital. For example, mandated policies and "best" practice may not qualify as corporate human capital if they are not universally applicable and valuable. The process of reconciliation at the unit level may reinforce the advice from headquarters or it may negate it. The process typically leads to adaptation, leading to a more robust knowledge base (cf., Ferner et al., 2004). Once again, this highlights the importance of attending to the social context as well as the cognitive, affective, and structural elements of relational capital that influence the emergence process of corporate human capital (Kang, Morris, \& Snell, 2007).

Corporate human capital within these units influences the further development of individual human capital. At first glance, because corporate human capital does not necessarily provide information unique to the local environment or the subsidiary, it may appear less distinctive or proprietary. However, corporate knowledge possessed by a collective talent pool can play a vital role in helping units stay closely integrated with the rest of the company.

Firm level. At the firm level, the emergence of corporate human capital is fundamentally different from local or subsidiary human capital. The formation of local and subsidiary human capital involves explicitly increasing customization of knowledge across business units. However, the formation of corporate human capital also involves reducing variation by generalizing those experiences to arrive at a knowledge set that is shared across the firm. In most cases, this process is done by contrasting firm-specific experience against norms or standard practice.

Importantly, the emergence of corporate human capital does not need to negate or displace subsidiary or local human capital. Though managing these different types of human capital as a set may be difficult, and the proportions of each may constitute a strategic choice, it is important to reinforce the idea that they are qualitatively distinct and serve different purposes in the MNC's human capital portfolio. 
From a competitive standpoint, the process that cultivates corporate human capital at the firm level provides the MNC with an asset that both is tested against the realities of various business units and is specific to the firm as a whole. The successive iterations that eventually develop corporate human capital can strengthen the firm's resolve and confidence in its knowledge and can lead to an identifying feature of the firm as a whole.

Hence, we propose the following:

P3: Developing corporate human capital helps to develop products, services, and practices that are unique to the firm and applicable to global clients.

\section{International Human Capital}

Often overlooked by both human capital and international business scholars, international human capital is low in both firm specificity and location specificity (Almeida, 1996). It can

include, for example, knowledge of global best practices, global industry standards, international trade laws, modular systems and processes, cross-border industry networks, and other transportable forms of experience that are applicable across multiple firms and countries. Consequently, it can be acquired externally or developed internally.

Theoretically speaking, we would acknowledge that international human capital provides no sustainable advantage to firms because it can be appropriated by rivals. However, such arguments are overly simplistic and inconsistent with reality. Deep international business expertise may represent a rare and valuable asset both within and across global industries and may be the foundation for distinct advantages in cross-border transactions and collaborations. For example, an individual with international human capital can help MNCs to overcome institutional voids (Ricart et al., 2004) and manage political risk. In fact, Khanna and Palepu (2000) have shown that even industries vary in performance across countries because of differences in understanding the international context. 
Individual level. People can develop international human capital by engaging in meaningful interactions with international experts and professional associations, closely observing global standards and new technologies, questioning the relevance of context specificity in knowledge, and identifying with a profession rather than a company (Cappelli, 2008). Research suggests that MNCs may inadvertently undervalue — and underutilize — employees with transportable international human capital (Caligiuri, Phillips, Lazarova, \& Tarique, 2001). For example, the associated challenges of repatriation often reflect the fact that subsidiaries struggle integrating employees with cross-border knowledge (Stahl \& Caligiuri, 2005). Yet such employees are more effective at networking across borders, understanding global business operations (Caligiuri \& Disanto, 2001), and coming up with innovative solutions for the company (Morris \& Snell, 2011).

In fact, most senior managers acquire strong international human capital because their experience in different locations, subsidiaries, and contexts gives them an understanding of how things work in order to transcend the organization. The obvious danger in developing "international gurus" is that it also creates highly mobile executives who may be versatile in their expertise and thus more valued by other firms. These individuals can realistically bring the market to bear in negotiating compensation terms, retention bonuses, and the like.

The key to retaining these employees is opportunities for upward mobility or for more responsibility and influence; however, those opportunities have terminal limits at executive levels. The challenge for firms, then, is to create opportunities for these individuals to do interesting — perhaps even proprietary or individualized — work, which shifts the balance of their personal human capital portfolio toward firm-specific knowledge relative to their cosmopolitan knowledge (Lepak \& Snell, 1999).

Unit level. At the unit level, international human capital is formed as individuals exchange their different knowledge and networks across a global setting. The formation of unit- 
level international human capital can be seen as a valuable resource in being able to apply knowledge directly from the external market to existing operations (Winter \& Szulanski, 2001).

Cosmopolitan expertise embedded within the unit can help subsidiaries stay on top of international standards and trends - something that can be otherwise detrimental to units focused only on local and firm-specific knowledge. In itself, this global market savvy may help distinguish units within a particular local market. However, a focus on building unit-level abilities around global standards creates administrative challenges for subsidiaries trying to fully utilize employees' collective knowledge that has been gathered from outside the firm.

Firm level. In relation to the entire MNC, this type of international human capital may be a vital source of competitive advantage, serving as the basis of being a more globally savvy player. This capability has proven valuable to globally effective companies such as $\mathrm{ABB}, \mathrm{P} \& \mathrm{G}$, and Nestle. Like corporate human capital, international human capital often helps overcome the issue of resource immobility within the firm and the firm's role in integrating knowledge from outside the firm.

International human capital is a potentially important source of expertise, to be sure. Nonetheless, if the development of international human capital is overemphasized at the expense of other forms of human capital, either intentionally or unintentionally, the MNC may inadvertently establish a human capital portfolio that is commoditized and indistinct. Firms in mature industries (including automobile, steel, pharmaceuticals, and energy) run this risk by promoting (and allowing) global industry standards and creating imitative isomorphism, rather than creating a distinguishable position. The commodity-like elements in their strategies become reflected in their human capital portfolio; thus, the strategic advantage in those cases can shift toward processes and technologies, rather than people. Hence, we propose the following:

\section{P4: Developing international human capital helps the MNC to stay on top of global best practices.}


In summary, we note in our premise that the talent portfolio of any MNC includes all four types of human capital (local, subsidiary, corporate, and international) in some proportion. The development of each form of human capital at the individual, unit, and firm levels does not just come as people begin to embed their individual knowledge in a social and organizational context; human capital development is also iterative as individual knowledge is simultaneously transformed by the social and organizational context as well. While developing each type of human capital is potentially valuable for the firm, the challenge in trying to create competitive advantage is how to manage the firm's talent pools in a way that will maximize the strategic benefits that derive from integrating and emphasizing the different types (Wright \& McMahan, 1992). In this regard, each type of human capital may provide strategic growth opportunities for the firm; however, it is when these different types of human capital are effectively integrated that firms are able to achieve competitive advantage.

\section{DEVELOPING AN ARCHITECTURAL PERSPECTIVE}

The four types of human capital and the three levels at which they are developed lay the foundation of a firm's global talent architecture. There is a natural tension among the four types of human capital; the development processes are generally opposing and involve tradeoffs for managers who must decide where to focus their knowledge integration efforts. Firms often make explicit decisions about both the form of this architecture as well as the function that it serves in generating and integrating knowledge within the enterprise. In terms of form, MNCs vary dramatically in the proportion of each type of human capital relative to the others in their portfolios. For example, some firms emphasize the development of local and subsidiary knowledge among their employees and deemphasize employees' degree of corporate or international knowledge. Other firms establish just the opposite attitude, preferring a talent portfolio that is weighted toward common corporate and international expertise. Still others work 
to strike a balance of all four types in order to link the expertise at particular locations to a firmwide knowledge base. While differences may be most pronounced by industry, differences exist among individual firms as well.

In addition to decisions about the proportion of each type of human capital, firms also differ in terms of their emphasis on levels of aggregation. For example, many firms approach human capital development as an individual-level phenomenon and focus on developing employees who possess unique skills or show the highest potential for performance. Other firms emphasize sharing knowledge to develop a more collective form of human capital (Dyer \& Nobeoka, 2000). Of course, these options are not mutually exclusive, and firms increasingly invest in all levels of human capital development.

What may be implicit in this discussion is that the form of the human capital architecture has direct parallels to the resource-based view of competitive advantage. Specifically, decisions about the types of human capital and levels of aggregation shape the configuration of resources available to the MNC to establish the basis for advantage relative to rivals. Different resource configurations provide different advantages to the MNC (e.g., local versus global). While there may be many viable design options, if firms are not explicit about the form of their global talent architecture, their human capital portfolio may develop inconsistently. Further, in many instances, without explicit attention to this architecture, the MNC may not have a clear indication of the substance of its human capital portfolio and therefore be unable to leverage the expertise that actually exists within the firm.

The form of the human capital architecture directly and crucially influences the way that it functions - the manner in which knowledge is generated, transferred, and integrated within the enterprise. In general, human capital architectures with more variety and heterogeneity are more likely to generate new knowledge from multiple points internally and externally within the environment. Conversely, human capital architectures with more consistency and collective 
aggregation are more likely to transfer and integrate knowledge, embedding it within the existing asset base of the MNC.

As will be discussed in detail in the following pages, effectively developing and integrating different forms of human capital based on a firm's international strategy allows the MNC to achieve competitive advantage (Kogut \& Zander, 1992; Smith, Collins, \& Clark, 2005). Different strategies require different forms of knowledge and different knowledge flows. Different strategies also create value in different ways. We examine three generic strategies of the $\mathrm{MNC}$ - multidomestic, meganational, and transnational — and the strategic value that comes from developing and integrating different forms of human capital. We also examine how the different forms of human capital can be developed and integrated across multiple levels through HR management. At the individual level, we focus on the specific HR practices for individual talent. At the unit level, we focus on the entire pool of talent within the unit. And at the firm level, the focus is on the HR orientation of the MNC (Taylor, Beechler, and Napier, 1996). The role of HR management is important at all of these levels because it shapes the combinative capabilities within the organization (Lengnick-Hall \& Lengnick-Hall, 2006).

\section{Human Capital and the Multidomestic Strategy}

A multidomestic strategy emphasizes the autonomy of regional businesses to operate independently in responding to local opportunities and challenges (Bartlett \& Ghoshal, 1989). This strategy involves a management structure that gives a great deal of discretion to local subsidiaries without much intervention from headquarters or operational coordination across units. Firms engaged in a multidomestic strategy are most likely to generate a competitive advantage when they adapt rapidly to arising circumstances in various regions and customize products and services for local clients.

In terms of the human capital architecture, the multidomestic strategy requires MNCs to develop capabilities that allow them to generate, combine, and integrate local human capital with 
subsidiary human capital, with comparatively less emphasis on corporate and international knowledge (see Figure 2). Local human capital in each of the disparate locations of the MNC is essential for generating opportunities, and subsidiary human capital helps situate that local knowledge within a firm-specific context. Since the various subsidiaries are given discretion to operate independently, adopting a multidomestic strategy nurtures considerable variety within the human capital portfolio that may be a source of new value creation.

[Insert Figure 2 about here]

Value creation by integrating local and subsidiary human capital. The value created by integrating local and subsidiary human capital involves combining different elements to increase how customers value using a particular product or service (Lepak, Smith, \& Taylor, 2007). Knowledge of the customer base in a particular market may be potentially valuable, but it is admittedly a local knowledge set that doesn't transfer well. However, if that local knowledge is complemented by knowledge of the firm's products and services—-particularly how those meet the clients' needs - the combination of those two sets of knowledge is both more valuable for and more specific to the firm. One way to get employees to integrate these two types of human capital is helping employees understand the importance of providing for clients' needs as well as finding new ways to address clients' unmet needs.

By continually integrating local with subsidiary human capital, we suggest that the firm will be able to increase the value of services and products provided in the local market (Helfat, 1994). In fact, this is where we see the codependence of subsidiary and local knowledge. Local human capital is used to help make economic, cultural, legal, and social connections with local clients, and it helps increase the appropriateness of a product or service. Yet such capabilities are not sufficient for a multidomestic strategy. Subsidiary human capital must also be combined with local human capital to render appropriate and novel products or services (Lepak, Takeuchi, \& Snell, 2003). The mechanism driving value comes as employees apply a deep-rooted 
understanding of the customer with a deep-rooted understanding of the subsidiary products and services. When employees have this combined knowledge, they are able to see what changes need to be made to the existing products to meet unique local needs. This form of knowledge integration provides a primary mechanism for organizational learning and innovation that helps to improve a firm's value proposition (Kogut \& Zander, 1992; Smith et al., 2005).

More important, because knowledge integration is focused on the local and subsidiary context, the different forms of human capital will be most effective at the individual and unit levels. Integration across units to the firm as a whole is much less prevalent. These points reinforce the knowledge-based perspective on the role of firms in integrating different knowledge elements. Much of the strategy literature tends to assume that knowledge will be automatically integrated within the firm. Unfortunately, the inherent nature of the firm does not ensure value creation through integration; rather, integration comes through proper coordination of employees and their human capital portfolios. As a result, firms that adopt a multidomestic strategy should focus on HR systems that encourage employees to integrate local human capital with subsidiary human capital at the local and subsidiary levels, with an overarching support structure from the MNC as a whole.

Individual-level HR. An individual approach to integrating local and subsidiary human capital may begin with staffing. To ensure strong local knowledge is present, current research suggests employees and managers for each subsidiary should be host country nationals (Heenan \& Perlmutter, 1979). Local employees should also be trained locally to ensure they develop a unique knowledge of the subsidiary that they can filter through their existing local knowledge. Unfortunately, employing only host country nationals does not allow for a more strongly integrated subsidiary culture that is unique to the local context; rather, this staffing approach may make the subsidiary too similar to other local competitors, lacking the distinctiveness of being a subsidiary of a foreign MNC. In addition, hiring only host country nationals limits the talent pool 
from which the company is drawing, as most of the employees in this situation will never reach the corporate level (Caligiuri \& Stroh, 1995).

Instead, firms should focus on staffing local units with a mix of parent country nationals, third-country nationals, and host country nationals and provide development that allows them to learn from one another and develop a subsidiary culture that is not only unique to the firm but also unique to the local context. These talent-management practices may focus on identifying and empowering employees to act on problems or opportunities that arise in situ in order to establish the foundation for organizational learning (Guthrie, 2001). Outcome-related incentives may also institutionalize a culture that emphasizes "creative abrasion" by encouraging subsidiary employees to constantly be thinking of ways to link contextually different ideas from the local environment and employee performance (Caligiuri et al., 2004). ${ }^{4}$ In essence, employees must be willing to make idiosyncratic knowledge investments that strongly develop their skills for the local context.

Of course, as noted previously, these talent-management practices must also focus on the retention of valued employees whose human capital is locally contextualized. For example, Newburry (2001) found that some degree of subunit interdependence with the rest of the corporation helped local employees perceive that their role in the subunit was less tenuous and more valuable to the firm. Therefore, managing employees' perceptions regarding their individual roles within the larger MNC may be important to employee retention. Law, Song, Wong, and Chen (2009) demonstrated that one way to increase local employee loyalty to the foreign subsidiary is for corporate headquarters to share more resources with the subsidiary and to allow more autonomy in how the employees use those resources.

\footnotetext{
${ }^{4}$ Note, however, that outcome-based incentives can also be detrimental when standardized processes need to be followed. For example, if the specified end result is maximizing shareholder value, then companies like Enron may engage in processes that result in short-run benefits but long-term harm to the company.
} 
Unit-level HR. Much of the responsibility for talent management and human capital development in the multidomestic firm rests at the unit level, and the core of HR investment often occurs there. Because subsidiary HR units are often given autonomy to customize or experiment with current practices as well as to develop new practices as a foundation for learning, they must develop "local creation" capabilities (Morris \& Snell, 2011) that help them integrate local and subsidiary knowledge. Developing these capabilities requires the HR functions within each subunit to create their own portfolio of external networks in order to adapt practices to meet local circumstances. For example, Stahl et al. (2012) argued that local HR systems should adopt hiring practices consistent with local environments. Doing so allows the MNC to develop talent pools with sufficient diversity to help the MNC adapt to changing environments. Hence, we argue that effectively implemented output-based HR systems will be efficient in helping subsidiaries generate knowledge from the local contexts (Turner \& Makhija, 2006).

In addition to generating local and subsidiary knowledge, HR units in a multidomestic firm also play a significant role in helping to collect, combine, and integrate that knowledge at the unit level. Although significant aggregation to the firm and corporate level is unlikely, integration at the unit level depends on HR practices that engender collaboration, particularly of market-related factors (Zellmer-Bruhn \& Gibson, 2006).

Firm-level HR. At a more macro firm level, managing the human capital architecture under a multidomestic strategy requires a corporate governance structure that enables decentralized decision making and flexibility in accommodating change. The firm-level HR function has a significant role to play in helping various business units develop their human capital base.

In regard to multidomestic strategy, HR systems will likely vary more across subsidiaries (Sparrow, Brewster, \& Harris, 2004). In fact, recent research suggests that nationally established 
patterns of managing subsidiaries have not disappeared in the face of globalization (Ngo, Loi, \& Folley, 2012). In these firms, talent-management approaches may not focus on integrating knowledge across all borders, but rather on integrating knowledge within the regional contexts (Myloni, Harzing, \& Mirza, 2004).

From a firm-level perspective, the HR function appears as a loose confederation of diverse operating units with a weak central network. This configuration allows separate business units to develop talent as necessary without much intervention from headquarters. Perlmutter (1969) referred to this as a "polycentric" approach to management. In this approach, there is an independent relationship between headquarter managers and subsidiary managers, although this is more typical of an MNC with long-established subsidiaries. Taylor, Beechler, and Napier (1996) refer to the corresponding HR orientation as "adaptive" in nature, in that the policies set by headquarters allows subsidiaries to make necessary adaptations to their HR practices and that those units are managed based on the achievement of preestablished outcomes or standards. Control theory (cf., Ouchi \& Maquire, 1975) suggests that organizational complexity and change tend to dimensionalize the cause-effect connections that allow for close headquarter scrutiny. As an alternative, firms may accord more discretion to subunits, holding them accountable for results. Importantly, while HR systems differ across operating units, the general philosophy around HR may not; the headquarters' function likely plays a significant role in establishing a common set of values and ethical standards. In these instances, clan or cultural control replaces bureaucratic solutions at the firm level (Ouchi, 1977).

P5: Firms with a multidomestic strategy will compete more effectively by building a talent portfolio that improves its capabilities to generate and integrate local and subsidiary human capital to not only help the firm interact with local clients and governments but also to offer unique solutions to local problems.

\section{Human Capital and the Meganational Strategy}


In contrast to multidomestic strategy, a meganational strategy emphasizes coordination and integration across business units to provide a common platform for the MNC (see Figure 3 ). Its governance structure is more central and formal to ensure consistent standards, processes, products, and services across business units (Bartlett \& Ghoshal, 1989). This strategy tends to establish the firm's competitive position in unified markets, where advantage depends on leveraging economies of scale and scope to achieve lower costs and global reach.

[Insert Figure 3 about here]

From the standpoint of the human capital architecture, employee expertise and experience in international human capital provides the foundation for established best practice and global savvy, and combining the international human capital with corporate human capital helps contextualize that knowledge in a way that reinforces a unified, yet firm-specific expertise. The primary difference between multidomestic and meganational strategies rests most notably on differences in levels of location specificity rather than differences in firm specificity—which runs counter to much of the strategy research on firm-specific advantages.

Value creation by integrating corporate and international human capital. The value created by integrating international with corporate human capital involves being able to effectively leverage products and services for global clients (Cantwell, 2009). Knowledge about international standards, trade laws, and cultures can be potentially valuable in a firm's internationalization efforts, but it is admittedly a very general knowledge set. However, if international knowledge is complemented with knowledge that is specific to the corporate operations and vision, this integrated human capital is valuable in being able to provide efficient products and services that are not only unique to the company but at the forefront of the company's industry.

The primary value created by integrating international and corporate human capital is that it is a source of best practice that can be applied wholesale. However, there is a secondary effect 
when these two human capital forms combine- the continual reallocation of resources to more productive combinations for use in a global context (Collins \& Smith, 2006). It reprioritizes the resources that are available for individual employees to combine with their existing knowledge. In other words, for human capital to be combined with other firm resources, that knowledge needs to first be moved within reach of the individuals and units combining it. Toyota's production system (cf., Dyer \& Hatch, 2006), for example, is a good illustration of this approach to human capital combination. The architecture in this case facilitates knowledge generation, transfer, and integration from all parts of the firm relevant to the MNC as a whole. At the extreme, this approach could limit the discretion of individual units in developing talent uniquely for their particular local and subsidiary contexts. However, developing local and subsidiary human capital under this strategy is necessary for tactical or administrative reasons (given the economic, political, and cultural realities of local environments), rather than desirable from a strategic point of view.

For instance, research on call centers has shown that local employees are not necessarily hired for their strong knowledge and skills related to the local environment. Rather, what creates strategic growth opportunities for these employees is their international human capital (e.g., accent neutralization, customer service skills, problem-solving abilities). When companies adopt a meganational strategy, it is the combination of this international human capital with corporate human capital (e.g., knowledge of the firm's global products, culture, and customer service values) that allows them to create value unique to their firms that is difficult for other firms to imitate. Hence, HR practices for a meganational strategy will differ from those for a multidomestic strategy.

Individual-level HR. Firms adopting a meganational strategy have traditionally focused on staffing their foreign units with expatriates in key management positions (Tung \& Punnett, 1993; Shaffer, Kraimer, Chen, \& Bolino, 2012). Such an approach allows for greater control of 
decision making and a more standardized approach to work (Kobrin, 1988), since expatriates are expected to standardize work and socialize host country nationals to a common culture.

However, scholars have shown that, given the nature of the socialization process, expatriates are usually less effective at promoting a meganational strategy (Lee \& Larwood, 1983). In fact, research suggest that such staffing practices make it less likely that the firm will be able to find top talent from the global market (Caligiuri \& Stroh, 1995).

To overcome issues related to relying on expatriates, a process-based HR orientation that focuses on helping local employees stay close to corporate and international standards may increase the employees' ability to integrate ideas across borders both inside and outside of the company. Unfortunately, one of the concerns about such policies is that by integrating knowledge of the international context with the corporate operations, employees become more strongly rooted to their professions rather than to their employing firms (Cappelli, 2008). And if the corporate policies are invariant or limit discretion, individuals may develop unsanctioned "workarounds" to achieve desired ends. As Feldman (2000) has pointed out, professional loyalty is often a much stronger force among top talent than compensation or commitment to a foreign firm. In addition, HR practices for individual managers, such as performance appraisals and compensation contingent on the transfer of knowledge, may provide individualized solutions to integration (Björkman, Barner-Rasmussen, \& Li, 2004).

For example, General Electric (GE) is known for a process-based HR orientation that encourages employees to integrate cutting-edge international knowledge and apply it to the global operations of each division. This approach means that many GE managers possess high levels of international human capital and, as a result, are poached by rival firms (Groysberg, McLean, \& Nohria, 2006). At the same time, however, it also means that GE usually creates a competitive advantage that other firms cannot imitate because the knowledge possessed by its employees is contextually embedded within both the international and corporate contexts. 
Unit-level HR. Efforts to globalize talent development imply HR practices at the unit level that are highly influenced if not directly controlled by headquarters (Taylor et al., 1996). In order to assure alignment and reinforce the development of corporate human capital, MNCs are likely to implement process-based HR systems that stipulate priorities, procedures, communication, and investments among business units (Kidger, 2002). Process-based systems help minimize divergence among highly dispersed subunits, which is important for both achieving economies of scale and reducing performance variance within the HR system as a whole.

However, the development of corporate human capital, supported by international human capital, may hinder the integration of more locally relevant knowledge. Furthermore, Andersson et al. (2005) have noted that process-based systems tend to decrease the connectedness of subsidiary units to local contacts outside the firm. This might decrease the development of local or subsidiary human capital, but it is also likely to place constraints on the development of relevant international human capital. And while this may be so, the role of the unit in an MNC following a meganational strategy is to cultivate relationships that generate globally relevant knowledge and best practice. The subsidiaries have an important role in implementing best practice, as well as identifying and sharing global best practice that may have applicability to the entire firm.

Business units concerned about minimizing deviations from the mandated processes may be influenced to maintain a narrow reach to local contacts that are readily available. Since they will not be rewarded for moving beyond a standardized approach, they are likely to deem the combination of knowledge from local contexts as less critical or valuable (Nebus, 2006). The process orientation encourages such behavior without allowing units to explore one-off relationships that might disrupt their standardized, but unique, corporate approach to offering 
value. In this regard, employees are able to combine international knowledge with corporate knowledge in a way that keeps the knowledge globally standardized and central to the MNC.

Firm-level HR. At the firm level, the HR governance structure reflects a centralized, tightly linked network of dependent units that operate in step with one another (cf., Taylor et al., 1996). Headquarters' directives may place a premium on consistency across subunits, and, to a large extent, this would represent the firm-specific adaptation and improvements on best practice. If the new knowledge is generated within the HR network itself, it will most likely take the form of deeper refinement, synthesis, and improvement of firm-level best HR practices (Morris et al., 2009).

This knowledge form serves two purposes with regard to the global talent architecture. First, centralized HR has the effect of creating synchronized talent development across the entire firm. For example, leadership development, succession planning, rotational assignments, and expatriation programs will likely be coordinated, if not administered directly, by headquarters personnel. As a result, human capital development takes on the characteristics of the corporate entity rather than only a smaller set of subsidiary experiences. Performance management and rewards systems, too, emphasize a firm-wide corporate orientation, further pointing employees toward the unique considerations of the MNC as a whole.

Second, this global approach enables knowledge sharing and organizational learning topdown, from the headquarters to the subsidiaries. To a lesser extent, it may facilitate the efforts of business units to share best practice laterally with one another. If the incentives allow, a global HR system can provide business units with a common framework (e.g., processes, systems, practices, terminology) for comparing, exchanging, and refining best practice with one another. Perhaps less likely is a bottom-up learning process where headquarters personnel learn from and synthesize knowledge from the business units (cf., Brown \& Duguid, 2001). Although the bottom-up and lateral approaches to knowledge sharing may be more difficult to achieve than 
top-down learning, they are the most viable for generating international human capital that is simultaneously specific to the MNC.

P6: Firms with a meganational strategy will compete more effectively by building a talent portfolio that improves its capabilities to generate and integrate international and corporate human capital to not only help the firm maintain global practices but also ensure those practices are unique to the firm.

\section{Human Capital and the Transnational Strategy}

The transnational strategy is often considered a hybrid strategy that combines the benefits of meganational and multidomestic strategies. Rather than viewing a transnational strategy as a compromise between global and local, this strategy achieves simultaneous local responsiveness and global integration. MNCs that successfully pursue a transnational strategy tend to adopt a governance structure that is both flexible and tightly integrated (see Figure 4). Like the multidomestic approach, the transnational strategy allows subsidiary discretion and autonomy to adapt and customize locally. However, unlike a meganational strategy that achieves integration through centralization and standardization by headquarters, the transnational achieves integration through close lateral coordination and a knowledge exchange that drives organizational learning among subsidiaries (Morris, Hammond, \& Snell, 2014).

\section{[Insert Figure 4 about here]}

The prerequisite for this strategic capability is a human capital architecture that supports continual knowledge flows, both internal and external, that allow for local adaptation and global integration (Bartlett \& Ghoshal, 1989; Kostova, 1999). To achieve this capability, emphasis should be placed on all four types of human capital: local, subsidiary, corporate, and international - albeit in different proportions. The combination of subsidiary and corporate human capital is most critical to the transnational strategy, as these two types are firm specific. However, their combination is both informed and contextualized by local human capital and international human capital. 
Value creation by integrating all forms of human capital. Local human capital provides the richness of experience that augments the development of subsidiary human capital; it also increases heterogeneity in the overall firm portfolio that stimulates innovation. International human capital, on the other hand, contextualizes the development of corporate human capital in relation to standards of practice that establish parity with rival firms. However, the bulk of value comes by integrating subsidiary with corporate human capital. Though both forms may seem almost antithetical to one another, the global-local tension inherent in the transnational model tends to be reconciled through a form of organizational ambidexterity that simultaneously achieves alignment and adaptability (Gibson \& Birkinshaw, 2004; Kang \& Snell, 2009).

Take, for instance, the case of Briggs \& Stratton. Employees in their China operations developed new products for the US-designed engines that were smaller, less bulky, and more in line with local customers' tastes (Washburn \& Hunsaker, 2011). While these new products were specifically designed for China, other employees were able to leverage the concepts and ideas behind these innovations in order to apply them across the entire organization. Because the Chinese employees were able to combine their knowledge of the local market with knowledge specific to Briggs \& Stratton, they were able to create new value for the Chinese subsidiary. In addition, because this knowledge was exchanged across borders, it acted as a catalyst for new value creation for the entire company.

In effect, new ideas from local workforce subunits can act as sources of creativity, best practice, and global solutions that create value for clients (Birkinshaw, 1997; Cantwell \& Mudambi, 2005). The primary value created by integrating local and subsidiary human capital with international and corporate human capital is that it becomes a source of new innovations that can be applied wholesale. However, there is a secondary effect: such human capital combinations can be a valuable capability in overcoming the immobility of location-specific knowledge, allowing the firm to leverage the value across locations. The challenge for firms in 
this context is to move beyond merely sharing or transferring knowledge and to make certain that this knowledge is actually integrated to create more value for customers, thus potentially creating specific value in each location (Almeida et al., 2002; Winter \& Szulanski, 2001). To understand how this integration might occur, we explore a unique set of coordination and control mechanisms that might be unique to a transnational approach.

Individual-level HR. At the individual level, the transnational MNC may develop employees whose human capital reflects the ambidexterity of global and local experience. In many instances, employees focus on local and subsidiary human capital, without much emphasis on corporate-wide integration. This may be sufficient for their individual purposes and contributions to the MNC. Other employees, however, such as those in senior positions or those closer to the strategic core of the firm, develop a more corporate and international orientation.

The challenge for the transnational is to build requisite variety into its human capital portfolio to address local differences while also ensuring connectivity within their portfolio guarantees global integration. But comparatively fewer individuals completely embody this duality, and the reality of most business units is that employees develop in different ways, for different purposes. In this case, MNCs should staff positions worldwide so that the best people are recruited for positions regardless of their nationality (Heenan \& Perlmutter, 1979).

In those cases where key individuals are challenged with developing a human capital profile that mirrors the characteristics of a transnational, they work to simultaneously establish external ties that connect them to the region, as well as internal ties that connect them to the MNC. Theirs is the challenge of contextual ambidexterity (Gibson \& Birkinshaw, 2004), working to reconcile for themselves, as well as for others, how their particular circumstances can be combined with a universal knowledge of the MNC as a whole. This contextual ambidexterity can be gained through strategic socialization processes that emphasize both national and corporate culture as valuable sources of knowledge. 
Unit-level HR. To understand how firms might balance this global-local tension requires a more micro examination at the unit level. The transnational MNC provides autonomy to the units, giving them freedom to adapt to local conditions while still holding them accountable for sharing and integrating knowledge globally. In many cases, headquarters provides broad HR policy directives or processes that are consistent across the MNC but demonstrate enough resource flexibility to be adapted for local practice. This approach provides the units latitude to develop human capital locally while still providing the internal consistency necessary for global integration.

Therefore, subunits in transnational MNCs will engage locally, building external networks for knowledge generation and customization. They can then aggregate and combine the human capital within the subsidiaries, helping to further reconcile shared experiences against corporate policies. While human capital development may not be identical across those different units within the MNC, the similarities are sufficiently recognizable to facilitate exchange and synthesis of subsidiary human capital with corporate human capital. The requirements of both coordination flexibility as well as resource flexibility apply here. When subunits develop human capital that has a common connection with policies or principles shared across the MNC, the knowledge developed by employees is more easily adapted to other locations - known as resource flexibility. Similarly, if subunits establish a norm of sharing and exchanging with other locations, then coordination flexibility is more likely as well. The combination of resource flexibility and coordination flexibility leads the subunits to easily integrate local and international human capital development.

Firm-level HR. At the firm level, the HR governance structure of a transnational strategy comprises a heterogeneous set of subsidiaries that develop human capital within their local contexts much the way a multidomestic strategy does. The firm supports this decentralized approach to ensure local responsiveness. This approach also serves as a source of firm-wide 
novelty and variation that leads to innovation. And just like the multidomestic model, HR systems within the transnational model tend to differ more across subsidiaries, reflecting local adaptation (Rosenzweig \& Nohria, 1994).

However, unlike the multidomestic model, there are significant reasons why initial variation across units trend toward uniformity within the MNC over time. Scholars have pointed out that a transnational orientation requires local knowledge resources to be acquired, compiled, exchanged, and transformed in order to promote new firm-specific ways of working; all of this must then be synthesized and refined across subsidiaries to the MNC as a whole. As the firmspecific subsidiary human capital is shared and each subsequent subsidiary adopts or adapts that knowledge to its own purposes, the mutual-learning process derives a set of general principles (or perhaps best practices) from a bottom-up approach. The net result is a "decentralized centralization" that continually generates knowledge informed by the multiple contexts while also providing consistencies that are firm specific.

The key challenge for the transnational firm is to facilitate the sharing and integration of this human capital without resorting to headquarter mandates. Indeed, Fey and Furu (2008) found that, counter to traditional research, providing subsidiary autonomy does not necessarily reduce coordination and integration among subsidiaries. If facilitated appropriately, autonomy can allow for a good deal of knowledge sharing. The role of headquarters is to enable this, encouraging and facilitating exchange rather than imposing it centrally. Human capital integration, in this context, enhances the position of the MNC by drawing upon and mutually (but not hierarchically) integrating unique ideas from other units (Harzing, 2000).

Because of the paradoxical nature of transnational strategies, requisite HR systems frequently reflect practices that allow for greater resource and coordination flexibility (Wright \& Snell, 1998). Resource flexibility refers to the extent to which HR practices or employees themselves are adaptive to a larger range of alternative contexts. Some HR practices - and 
indeed some employees - are for a special purpose and are valuable in a fairly narrow range of contexts. Other practices are more malleable and can adapt more readily. Related to this, coordination flexibility refers to the firm's ability to reconfigure its portfolio of resources and redeploy them rapidly to alternative purposes (cf., Kalleberg, 2001). This may include both physical and virtual redeployment of human capital. For example, firms may establish knowledge exchanges across countries, either by transferring employees, sharing knowledge through social networks, sharing through portals and information systems, or replicating through documented processes and best practices (Dyer \& Singh, 1998).

Both resource and coordination flexibility help the transnational firm build an HR organization that enables continual learning and has the capacity to leverage that learning globally. From the MNC perspective, ensuring consistency in the midst of variation requires adopting an overarching, globally flexible HR orientation. Such an orientation encourages employees to span their learning across country and company contexts but also to stay close and interested in building knowledge that is consistent across the firm. (Figure 5 lays out a simple way to examine the different HR responses to these three strategies).

\section{P7: Firms with a transnational strategy will compete more effectively by building a talent portfolio that improves its capabilities to generate and integrate subsidiary and corporate human capital to help the firm learn from its subsidiaries and leverage them across the corporation.}

[Insert Figure 5 about here]

\section{DISCUSSION}

Adopting an architectural perspective helps us view both the form and function of an MNC's human capital portfolio. In fact, viewing human capital as part of a firm's knowledge assets helps us pay closer attention to how human capital is effectively integrated based on a firm's international strategy orientation. 
Indeed, knowledge-based views recognize heterogeneity of knowledge elements as the foundation of all competitive advantage. This view has tended to remain atheoretical in regard to explaining the function of these knowledge forms because it attributes the source of new knowledge to unexpected changes (Rumelt, 1984), luck, and foresight (Barney, 1986). Our purpose was to provide a contextually relevant theoretical approach to competitive advantage in the MNC by describing the development of different types of knowledge sources within a firm's talent portfolio and then examining how these different types of knowledge might be integrated.

Lepak and Snell (1999) and Kang et al. (2007) have pointed out how different forms of human capital might provide different sources of value for the firm and how these different forms of human capital can be integrated to explore a firm's knowledge. Our paper builds on this research by, first, examining how the global context might change our traditional views of human capital and its value proposition. Counter to Lepak and Snell (1999), we point out that, in a global context, organizations often find strategic value from employees who possess forms of human capital that go beyond the firm-specific level. We examined these forms of human capital by juxtaposing the firm and market contexts, moving away from resource-based notions of uniqueness and value as primary factors driving human capital decisions. Second, we explored how these different forms of human capital might be integrated to create unique forms of value for the firm. While myriad combinations of human capital are likely to create unique sources of value, we limit our discussion of combinations to those most relevant to international strategies used by MNCs. Future research might explore different human capital combinations and their potential to create unique value for the firm.

The presented architecture suggests that it is not the internalization of different types of human capital that lies at the heart of competitive advantage. Rather, MNCs create competitive advantage by developing different contextually embedded forms of human capital at the individual, unit, and firm levels over time (Dierixck \& Cool, 1989), and then strategically 
integrating these forms within the MNC (see Figure 6 to see how this framework can be used to inform management). While other types of human capital (e.g., project-specific) exist within the MNC, by addressing location specificity and firm specificity, we have developed a framework that can be generalized to effectively identify a firm's human capital portfolio and suggest how that portfolio might be strategically leveraged to create competitive advantage. We have thereby increased our theoretical understanding of how firms can overcome geographic and operational distance in their workforce setting. For instance, integrating knowledge from people in one location with nonoverlapping knowledge found inside the firm can generate new ideas. In this way, the type of human capital integrated not only influences what human capital gets used but also how that knowledge helps a firm to achieve strategic advantage.

[Insert Figure 6 about here]

In addition, the human capital architecture offers an alternative knowledge-based model rather than the traditional demographic-based model that examines staffing decisions based on whether someone is native to the country or originally from headquarters. This helps the staffing literature examine people based on their knowledge portfolio, regardless of where they are from or where they are currently located. For example, companies that adopt a strong global strategy do not need to turn to parent country nationals to ensure that knowledge is integrated and standardized across borders; rather, these companies should staff people with strong levels of corporate human capital combined with international human capital. This perspective moves beyond alignment of HR practices with strategy by discussing how the dynamic capability to integrate different forms of human capital at multiple levels creates the increased social complexity and causal ambiguity that are difficult for competing firms to imitate or copy.

\section{Research Agenda}

Coff (1999: 120) noted that a primary flaw of theories of the firm research is "the overly simplistic definition of a firm." Scholars often assume that when a firm internalizes human 
capital, the firm owns it — or at least owns the rights to capture the value from that human capital (e.g., Barney, 1991; Williamson, 1985). However, in most cases, it is unrealistic to assume that firms can own knowledge-based assets (cf., Coff, 2010; Foss \& Foss, 2008). As a result, the MNC can be seen as a nexus of different configurations of knowledge-based assets that, to a large extent, are embedded within people. How effectively human capital is combined and exchanged with firm-specific resources determines the portfolio of knowledge possessed by its individual employees, subsidiaries, and the MNC as a whole.

The human capital architecture provides a framework from which to understand the dynamic portfolio of talent within the MNC and how the various interactions among individuallevel, unit-level, and firm-level knowledge can influence the MNC's ability to create and capture value in a fluid, global business environment. Employees often possess a portfolio representing aspects of local, subsidiary, corporate, and international human capital. Part of the challenge in understanding these complexities and how they might be influenced by HR comes from how human capital is measured. In other words, rather than aggregating these forms of human capital across the organization, we also need to understand how they interact with other firm-based resources to generate unit-level and firm-level human capital that is tied to both social and organizational factors (Morris \& Snell, 2011).

Individual-level measurement. When hired into the firm, employees possess a specific level of local and international human capital. Since most new hires have not worked in multiple countries, they rarely possess large pools of international human capital. With little exception, distinctions have not been made to understand the difference between an individual's crossborder knowledge that is tied to a particular firm (corporate human capital) and the cross-border knowledge that is tied to multiple firms and usually applicable across organizations and sometimes even industries (international human capital). Based on the global talent architecture, much of this difference lies in how the individual is tied to other peers within the firm versus 
outside of the firm and how familiar that person is with the MNC's specific processes, systems, and practices.

For example, in a study of cosmopolitans and locals, Haas (2006) found that the human capital portfolio that individuals possess impacts their project-level performance. Seeing a need to move beyond traditional expatriate research, Haas emphasized the importance of distinguishing between types of human capital possessed by employees in subsidiaries. Using the "cosmopolitan-local" classification scheme to examine the level of experience for local hires, she categorized team members according to their experience and knowledge base. In this regard, local and international human capital can be determined by assessing employees' international experience and education outside of the MNC. Subsidiary human capital can be determined further by examining the employee's individual social networks and use of subsidiary routines, processes, and systems. The more employees that use these mechanisms, the greater their subsidiary human capital, and, potentially, their ability to create value for the firm. Corporate human capital can be determined by examining how much these individuals exchange information with peers and use databases outside of the country but inside the firm.

Based on the arguments posited in this paper, once you have measured this portfolio of human capital, you can test it against performance measures of individual employees to assess what level of value each employee is creating for the firm. You can also assess the salary level of these employees compared to the average market wages. If they are paid above market rates, then you might surmise that they are capturing more of the value than the firm, although both may still benefit (Coff, 1999). Under such circumstances, we expect employees to possess a strong portfolio of local and international human capital, making them visible and attractive to competitors.

Unit-level measurement. Subsidiaries are also composed of a particular human capital portfolio, which allows them to contribute to a firm's competitive advantage. In reality, units 
present a nesting problem for measurement. Within the MNC, individuals may cross multiple units within a country or even across countries (Mathieu \& Chen, 2010). Units might be embedded within other units and employees might be embedded within multiple units. Such problems require that researchers become more involved with the data they are examining. One way to do this is to engage in more detailed qualitative data to understand where the boundaries exist and to help make meaningful differences for purposes of analysis. For example, Farndale, Scullion, et al. (2010) conducted in-depth interviews with HR managers at multiple levels within a series of MNCs to ensure that their study was focused on the correct unit level of analysis. Once this was determined, they conducted further qualitative analyses to understand the role of HR subunits within MNCs.

This human capital portfolio not only represents an aggregate level of human capital of all its employees, but it also represents a socially and organizationally embedded set of knowledge collectively realized at the subsidiary level. For example, as subsidiaries localize their operations, they must combine the knowledge of their local hires with the knowledge and resources specific to the subsidiary. This is done by getting local experts to develop social relationships with managers and coworkers in order to develop a team production model. Getting local experts to adopt subsidiary-level processes, systems, and practices to help them with their work will achieve this end result as well. Both social and organizational capital development increase the social complexity, causal ambiguity, and firm specificity of local experts' knowledge. A subsidiary that does this combination process well may have a stronger portfolio of subsidiary human capital than it has of local and international human capital.

Morris and Snell (2011) measured subsidiary-level local and international human capital by examining how much international experience, training, and education each employee had outside the firm but within the same industry. This was then aggregated to the subsidiary level. To assess how much this human capital was specific to the MNC as a whole (corporate human 
capital), the researchers examined the extent to which employees from these subsidiaries exchanged knowledge with employees in other subsidiaries and how often they used and contributed to globally integrated information systems, processes, and routines.

To assess how specific this knowledge is to the subsidiary (subsidiary human capital), scholars can examine the network ties within the subsidiary and determine to what extent the routines, processes, and systems are utilized within the subsidiary. Such measures will help determine the human capital portfolio for an MNC subsidiary. To test which human capital configurations are most effective, scholars can assess how much revenue is generated by the subsidiary itself (value creation) and then assess how much of that value is sent to headquarters, used to pay employees, or reinvested into the subsidiary itself (value capture).

Firm-level measurement. If you were to analyze MNCs from a knowledge-based perspective, you would need to examine how different human capital portfolios might lead to different outcomes for different MNCs. Such a level of analysis may also capture the overarching strategy of the firm, as a multidomestic strategy would likely lead to a much larger portfolio of local and subsidiary human capital. MNCs with strong local expertise may be especially good at creating value locally but may not be good at capturing or leveraging that value for the entire firm. As a result, MNCs using a transnational strategy want a mix of both local and subsidiary human capital, coupled with strong levels of corporate human capital that allow them to capture much of the value created by subsidiaries - and in the process, create new value for the MNC as well.

Measuring firm-level human capital requires assessing human capital portfolios at the subsidiary level. Subsidiaries that carry large amounts of corporate human capital are thoroughly integrated and frequently exchange knowledge. This is because the people within each subsidiary use social networks, routines, processes, and systems to share knowledge with one another. This exchange also leads to greater understanding among employees of how and when to apply their 
knowledge to help the organization as a whole, and aids them in finding knowledge in the MNC that will benefit the subsidiary unit. Such research is not limited to traditional quantitative methods, and should be explored using multidisciplinary collaborations (Farndale, Paauwe, et al., 2010), qualitative research, and longitudinal research designs.

Building bridges across the levels. Keep in mind that whenever research traverses multiple levels, you need to be careful at what level you articulate the theoretical basis (Hitt, Beamish, Jackson, \& Mathieu, 2007; Molloy, Ployhart, \& Wright, 2011). Levels of theory refer to the levels at which generalizations are meant to apply (Rousseau, 1995). The generalizations herein for the human capital architecture are meant to be generalized at the firm level, but certainly such a framework could be generalized at multiple levels. In general, a good rule of thumb is that the level at which you formulate your hypotheses is the level of theory. Developing separate theories for multiple levels is possible, but you should make sure that theorizing and measurement are consistent with the hypotheses. In fact, much of the real-world problems faced by organizations — such as global outsourcing, healthcare management, bribery and corruption, political risk, and poverty — are embedded in multiple-level issues that need to be both analyzed and theorized at multiple levels (Hitt et al., 2007). To aid in such complex research, advances in multilevel modeling help increase precision for quantitative research. For example, multilevel modeling has become available for analyzing dichotomous, nominal, count, and ordinal dependent variables (Peterson, Arregle, \& Martin, 2012). Indeed, there is still a dearth of studies using multilevel analysis in the international business arena.

To make things more complex, Cascio (2012) has shown that precautions must be taken when conducting international research on people within organizations. For example, examining data across cultures and languages presents translation issues for measurement. Defining the populations that need to be examined can also create problems because of the nesting issues mentioned above. Solutions to these methodological problems when analyzing multiple level 
data include, for example, using multiple databases and multiple research methods to define and list populations of interest and to ensure you are getting the correct level of analysis. In addition, longitudinal data can help overcome problems related to causation.

Overall, conducting research on global talent management presents an alternative framework for examining the MNC. This framework demonstrates that the MNC is really a nexus of various forms of human capital that are combined and exchanged with each other. Because human assets have the greatest potential to create value for the firm, it is important for managers to understand how to effectively measure and analyze knowledge from their employees. Such an understanding helps identify how human capital, as a strategic resource, can lead to competitive advantage for the MNC.

\section{CONCLUSION}

We have presented an architecture for global talent management to extend existing knowledge-based views and human capital theories within the global context. In so doing, we hoped to build new assumptions of geographic distance and operational differences. The first step in our extension examined an additional form of human capital specificity—one related to geographic context rather than organizational boundaries. In the next step, we identified the individual-level to unit-level to firm-level development of four different forms of human capital found within the firm. To show this, we juxtaposed firm-specificity with geographic specificity in order to determine the origin of knowledge within the firm. Next, we examined how different types of human capital integration might lead to competitive advantage, depending on the firm's strategy. In addition to examining how different international strategies might lead to competitive advantage, we examined the role of HR management in developing capabilities that allow firms to actually implement these strategies within the human capital framework from individual, unit, and firm levels. Finally, we proposed a future research agenda to help examine this framework from a global talent management perspective. Hopefully future research can help 
companies to more effectively manage their talent portfolios to increase global competitiveness in an ever-changing world. 


\section{REFERENCES}

Almeida, P. 1996. Knowledge sourcing by foreign multinationals: Patent citation analysis in the U.S. semiconductor industry. Strategic Management Journal, 17(Winter Special Issue), $155-165$.

Almeida, P., Song, J., \& Grant, R. 2002. Are firms superior to alliances and markets? An empirical test of cross-border knowledge building. Organization Science, 13(2), 147161.

Andersson, U., Björkman, I., \& Forsgren, M. 2005. Managing subsidiary knowledge creation: The effect of control mechanisms on subsidiary local embeddedness. International Business Review, 14(5), 521-538.

Barney, J. B. 1986. Strategic market factors: Expectations, luck, and business strategy. Management Science, 32(10), 1231-1241.

Barney, J. B. 1991. Firm resources and sustained competitive advantage. Journal of Management, 17(1), 99-120.

Bartlett, C., \& Ghoshal. S. 1989. Managing across borders: The transnational solution. Cambridge, MA: Harvard Business Press.

Becker, G. 1964. Human capital: A theoretical and empirical analysis, with special reference to education. New York: National Bureau of Economic Research.

Birkinshaw, J. 1997. Entrepreneurship in multinational corporations: The characteristics of subsidiary indicatives. Strategic Management Journal, 18(3), 207-229.

Björkman, I., Barner-Rasmussen, W., \& Li, L. 2004. Managing knowledge transfer in MNCs: The impact of headquarters control mechanisms. Journal of International Business Studies, 35(5), 443-455.

M. Fruin, \& P. S. Adler (Eds.), Remade in America: Transplanting Japanese management systems. Oxford, UK: Oxford University Press.

Brown, J. S., \& Duguid, P. 2001. Knowledge and organization: A social-practice perspective. Organization Science, 12(2), 198-213.

Caligiuri, P. 2013. Cultural agility: Building a pipeline of successful global professionals. San Francisco, CA: John Wiley \& Sons.

Caligiuri, P., \& Di Santo, V. (2001). Global competence: what is it, and can it be developed through global assignments?. People and Strategy, 24(3), 27.

Caligiuri, P. M., Lazarova, M., 2001. Strategic repatriation policies to enhance global leadership development. Developing Global Business Leaders, 243-256. 
Caligiuri, P., Lazarova, M., \& Zehetbauer, S. 2004. Top managers' national diversity and boundary spanning: Attitudinal indicators of a firm's internationalization. Journal of Management Development, 23(9), 848-859.

Caligiuri, P., Phillips, J., Lazarova, M., Tarique, I., \& Burgi, P. 2001. The theory of met expectations applied to expatriate adjustment: The role of crosscultural training. International Journal of Human Resource Management, 12(3), 357-372.

Caligiuri, P. M., \& Stroh, L. K. 1995. Multinational corporation management strategies and international human resources practices: Bringing IHRM to the bottom line. International Journal of Human Resource Management, 6(3), 494-507.

Campbell, B., Coff, R., \& Kryscynski, D. 2011. Re-thinking competitive advantage from human capital. Academy of Management Review, 37(3), 376-395.

Cantwell, J. 2009. Location and the multinational enterprise. Journal of International Business Studies, 40, 35-41.

Cantwell, J., \& Mudambi, R. 2005. MNC competence-creating subsidiary mandates. Strategic Management Journal, 26, 1109-1128.

Cappelli, P. 2008. Talent on demand: Managing talent in an age of uncertainty. Cambridge, MA: Harvard Business Press.

Cappelli, P., \& Keller, J. R. 2014. Talent Management: Conceptual approaches and practical challenges. Annual Review of Organizational Psychology and Organizational Behavior, 1(1), 305-331.

Cascio, W. F. 2012. Methodological issues in international HR management research. International Journal of Human Resource Management, 23(12), 2532-2545.

Coff, R. W. 1999. When competitive advantage doesn't lead to performance: The resource-based view and stakeholder bargaining power. Organization Science, 10(2), 119-133.

Coff, R. W. 2010. The coevolution of rent appropriation and capability development. Strategic Management Journal, 31(7), 711-733.

Collins, C. J., \& Smith, K. G. 2006. Knowledge exchange and combination: The role of human resource practices in the performance of high-technology firms. Academy of Management Journal, 49(3), 544-560.

Dierixck I., \& Cool, K. 1989. Asset stock accumulation and sustainability of competitive advantage. Management Science, 35(12), 1504-1511.

Doz, Y. L., \& Santos, J. F. P. 1997. On the management of knowledge: from the transparency of collocation and cossetting to the quandary of dispersion and differentiation. Fontainebleau, France: INSEAD, mimeo. 
Doz, Y. L., Santos, J., \& Williamson, P. 2001. From global to metanational: How companies win in the knowledge economy. Boston, MA: Harvard Business Press.

Dyer, J. H., \& Nobeoka, K. 2000. Creating and managing a high performance knowledge sharing network: The case of Toyota. Strategic Management Journal, 21(Special Issue), 345367.

Dyer, J. H., \& Singh, H. 1998. The relational view: Cooperative strategy and sources of interorganizational competitive advantage. Academy of Management Review, 23(4), 660 679.

Dyer, J. H., Hatch, N. W., 2006. Relation-specific capabilities and barriers to knowledge transfers: Creating advantage through network relationships. Strategic Management Journal, 27(8), 701-719.

Farndale, E., Paauwe, J., Morris, S. S., Stahl, G. K., Stiles, P., Trevor, J., \& Wright, P. M. 2010. Context-bound configurations of corporate HR functions in multinational corporations. Human Resource Management, 49(1), 45-66.

Farndale, E., Scullion, H., \& Sparrow, P. 2010. The role of the corporate HR function in global talent management. Journal of World Business, 45, 161-168.

Feldman, M. S. 2000. Organizational routines as a source of continuous change. Organization Science, 11(6), 611-629.

Fey, C. F., \& Furu, P. 2008. Top management compensation and knowledge sharing in multinational corporations. Strategic Management Journal, 29(12), 1301-1323.

Foss, K., \& Foss, N. J. 2008. Understanding opportunity discovery and sustainable advantage: The role of transaction costs and property rights. Strategic Entrepreneurship Journal, 2(3), 191-207.

Foss, N. J., \& Pedersen, T. 2004. Governing knowledge processes in the multinational corporation. Journal of International Business Studies, 35, 340-349.

Gibson, C. B. \& Birkinshaw, J. 2004. The antecedents, consequences, and mediating role of organizational ambidexterity. Academy of Management Journal, 47(2), 209-226.

Groysberg, B., Lee, L. E., \& Nanda, A. 2008. Can they take it with them? The portability of star knowledge workers' performance. Management Science, 54(7), 1-18.

Groysberg, B., McLean, A. N., \& Nohria, N. 2006. Are leaders portable? Harvard Business Review, 84(5), 92.

Guthrie, J. P. 2001. High-involvement work practices, turnover, and productivity: Evidence from New Zealand. Academy of Management Journal, 44(1), 180-190.

Haas, M. R. 2006. Acquiring and applying knowledge in transnational teams: The roles of cosmopolitans and locals. Organization Science, 17(3), 367-384. 
Harzing, A., 2000. An empirical analysis and extension of the Bartlett and Ghoshal typology of multinational companies. Journal of International Business Studies, 31(1), 101-120.

Hatch, N. W., \& Dyer, J. H. 2004. Human capital and learning as a source of sustainable competitive advantage. Strategic Management Journal, 25(12), 1155-1178.

Heenan, D. A., \& Perlmutter, H. V. 1979. Multinational organization development. Reading, MA: Addison-Wesley Publishing Company.

Helfat, C. E. 1994. Evolutionary trajectories in petroleum firm R\&D. Management Science, 40(12), 1720-1747.

Hitt, M. A., Beamish, P. W., Jackson, S. E., \& Mathieu, J. E. 2007. Building theoretical and empirical bridges across levels: Multilevel research in management. Academy of Management Journal, 50(6), 1385-1399.

Inkpen, A. C. 1997. Knowledge, bargaining power, and the instability of international joint ventures. Academy of Management Review, 22(1), 177-202.

Isobe, T., Makino, S., \& Montgomery, D. B. 2000. Resource commitment, entry timing, and market performance of foreign direct investments in emerging economies: The case of Japanese international joint ventures in China. Academy of Management Journal, 43(3), $468-484$.

Joshi, A., Labianca, G., \& Caligiuri, P. 2002. Getting along long distance: Understanding conflict in a multinational team through social network analysis. Journal of World Business, 37, 277-284.

Kalleberg, A. L. 2001. Organizing flexibility: the flexible firm in a new century. British Journal of Industrial Relations, 39(4), 479-504.

Kang, S. C., \& Snell, S. A. 2009. Intellectual capital architectures and ambidextrous learning: a framework for human resource management. Journal of Management Studies, 46(1), 6592.

Kang, S. K., Morris, S. S., \& Snell, S. A. 2007. Relational archetypes, organizational learning, and value creation: Extending the human resource architecture. Academy of Management Review, 32(1), 236-256.

Khanna, T., \& Palepu, K. 2000. The future of business groups in emerging markets: Long-run evidence from Chile. Academy of Management Journal, 43(3), 268-285.

Kidger, P. J. 2002. Management structure in multinational enterprises: Responding to globalisation. Employee Relations, 24(1), 69-85.

Kobrin, S. J. 1988. Expatriate reduction and strategic control in American multinational corporations. Human Resource Management, 27(1): 63-75. 
Kogut, B., \& Zander, U. 1992. Knowledge of the firm, combinative capabilities, and the replication of technology. Organization Science, 3, 387-397.

Kogut, B., \& Zander, U. 1993. Knowledge of the firm and the evolutionary theory of the multinational corporation. Journal of International Business Studies, 24(4), 625-645.

Kozlowski, S. W. \& Klein, K. J., 2000. From micro to meso: Critical steps in conceptualizing and conducting multilevel research. Organizational Research Methods, 3(3), 211-236.

Kostova, T. 1999. Transnational transfer of strategic organizational practices: A contextual perspective. Academy of Management Review, 24(2), 308-324.

Krupka, D. J. 2007. Are big cities more segregated? Neighbourhood scale and the measurement of segregation. Urban Studies, 44(1), 187-197.

Kumar, K., van Fenema, P. C., \& Von Glinow, M. A. 2005. Intense collaboration in globally distributed work teams: Evolving patterns of dependencies and coordination. Advances in International Management, 18, 127-153.

Law, K. S., Song, L. J., Wong, C.-S., \& Chen, D. 2009. The antecedents and consequences of successful localization. Journal of International Business Studies, 40(8), 1359-1373.

Lazarova, M. \& Tarique, I., 2005. Knowledge transfer upon repatriation. Journal of World Business, 40(4), 361-373.

Lee, Y., \& Larwood, L. 1983. The socialization of expatriate managers in multinational firms. Academy of Management Journal, 26(4), 657-665.

Lengnick-Hall, C. A., \& Lengnick-Hall, M. L. 2006. HR, ERP, and competitive advantage. Human Resource Management, 45, 179-194.

Lepak, D. P., Smith, K. G., \& Taylor, M. S. 2007. Value creation and value capture: A multilevel perspective. Academy of Management Review, 32(1), 180-194.

Lepak, D. P., \& Snell, S. A. 1999. The human resource architecture: Toward a theory of human capital allocation and development. Academy of Management Review, 24(1), 31-48.

Lepak, D. P., Takeuchi, R., \& Snell, S. A. 2003. Employment flexibility and firm performance: Examining the interaction effects of employment mode, environmental dynamism, and technological intensity. Journal of Management, 29(5), 681-703.

Mackey, A., Molloy, J., \& Morris, S. 2014. Scarce human capital in managerial labor markets: Implications for strategic human capital scholarship. Journal of Management, 40(2): 399421.

Mathieu, J. E., \& Chen, G. 2010. The etiology of the multilevel paradigm in management research. Journal of Management, 37(2), 610-641. 
Molloy, J. C., Ployhart, R. E., \& Wright, P. M. 2011. The myth of "the" micro-macro divide:

Bridging system-level and disciplinary divides. Journal of Management, 37(2), 581-609.

Morris, S., Alvarez, S., Barney, J., \& Molloy, J. 2013. Firm-specific human capital as a signal of general value: Revisiting assumptions about human capital and how it is managed. Unpublished working paper, Marriott School of Management, Brigham Young University.

Morris, S., Hammond, R., \& Snell, S., 2014. A microfoundations approach to transnational capabilities: The role of knowledge search in an ever-changing world. Journal of International Business Studies, 45(4), 405-427.

Morris, S. S., \& Snell, S. A. 2011. Intellectual capital configurations and organizational capability: An empirical examination of human resource subunits in the multinational enterprise. Journal of International Business Studies, 42, 805-827.

Morris, S. S., Wright, P. M., Trevor, J., Stiles, P., Stahl, G. K., Snell, S., . . \& Farndale, E. 2009. Global challenges to replicating HR: The role of people, processes, and systems. Human Resource Management, 48(6), 973-995.

Myloni, B., Harzing, A. W. K., \& Mirza, H. 2004. Host country specific factors and the transfer of human resource management practices in multinational companies. International journal of Manpower, 25(6), 518-534.

Nebus, J. 2006. Building collegial information networks: A theory of advice network generation. Academy of Management Review, 31(3), 615-637.

Newburry, W., 2001. MNC interdependence and local embeddedness influences on perceptions of career benefits from global integration. Journal of International Business Studies, 32(3), 497-507.

Ngo, H. Y., Loi, R., \& Foley, S. 2012. Human resource flexibility in foreign subsidiaries: An empirical investigation in Hong Kong. International Journal of Business Studies, 20(1), 11.

Oldroyd, J. B., \& Morris, S. S. 2012. Catching falling stars: A human resource response to social capital's detrimental effect of information overload on star employees. Academy of Management Review, 37(3), 396-418.

Ouchi, W. G. 1977. The relationship between organizational structure and organizational control. Administrative Science Quarterly, 22(1), 95-113.

Ouchi, W. G., \& Maguire, M. A. 1975. Organizational control: Two functions. Administrative Science Quarterly, 20(4), 559-569.

Perlmutter, H. V. 1969. The Tortuous Evolution of Multinational Enterprises. Journal of World Business, 1, 9-18. 
Peterson, M. F., Arregle, J.-L., and Martin, X. 2012. Multilevel models in international business research. Journal of International Business Studies, 43, 451-457.

Ployhart, R. E., \& Moliterno, T. P. 2011. Emergence of the human capital resource: A multilevel model. Academy of Management Review, 36(1), 127-150.

Pucik, V., Evans, P., Bjorkman, P., Morris, S. 2016. The global challenge: International human resource management. Chicago Business Press, Chicago.

Reiche, B. S., Harzing, A., \& Kraimer, M. L. 2009. The role of international assignees' social capital in creating inter-unit intellectual capital: A cross-level model. Journal of International Business Studies, 40(3), 509-526.

Ricart, J. E., Enright, M. J., Ghemawat, P., Hart, S. L., \& Khanna, T. 2004. New frontiers in international strategy. Journal of International Business Studies, 35(3), 175-200.

Riordan, M. H. \& Williamson, O. E., 1985. Asset specificity and economic organization. International Journal of Industrial Organization, 3(4), 365-378.

Rosenthal, S. S., \& Strange, W. C. 2008. The attenuation of human capital spillovers. Journal of Urban Economics, Elsevier, 64(2), 373-389.

Rosenzweig, P. M., \& Nohria, N. 1994. Influences on human resource management practices in multinational corporations. Journal of International Business Studies, 25(2), 229-251.

Rousseau, D. M. 1995. Psychological contracts in organizations. Thousand Oaks, CA: Sage.

Rumelt, R. P. 1984. Towards a strategic theory of the firm. In R. B. Lamb (Ed.), Competitive strategic management (pp. 556-570). Englewood Cliffs, NJ: Prentice-Hall.

Schuler, R. S., Jackson, S. E., \& Tarique, I., 2011. Global talent management and global talent challenges: Strategic opportunities for IHRM. Journal of World Business, 46(4), 506516.

Schulz, M. 2001. The uncertain relevance of newness: Organizational learning and knowledge flows. Academy of Management Journal, 44(4), 661-681.

Scullion, H. \& Collings, D. G. 2011. Global talent management. New York City, NY: Routledge.

Shaffer, M. A., Kraimer, M. L., Chen, Y. P., \& Bolino, M. C. 2012. Choices, challenges, and career consequences of global work experiences: A review and future agenda, Journal of Management, 38, 1282-1327.

Shenkar, O. 2004. One more time: International business in a global economy. Journal of International Business Studies, 35(2), 161-171. 
Smith, K., Collins, C., \& Clark, K. 2005. Existing knowledge, knowledge creation capability, and the rate of new product introduction in high-technology firms. Academy of Management Journal, 48, 346-357.

Somaya, D., \& Williamson, I. O. 2008. Rethinking the 'war for talent'. MIT Sloan Management Review, 49(4), 29-34.

Sparrow, P., Brewster, C., \& Harris, H. 2004. Globalizing human resource management. London: Routledge.

Stahl, G. K., \& Caligiuri, P. 2005. The effectiveness of expatriate coping strategies: the moderating role of cultural distance, position level, and time on the international assignment. Journal of Applied Psychology, 90(4), 603.

Stahl, G., Björkman, I., Farndale, E., Morris, S. S., Paauwe, J., Stiles, P., . . \& \& Wright, P. 2012. Six principles of effective global talent management. Sloan Management Review, 53(2), $25-42$.

Taylor, S., Beechler, S., \& Napier, N. 1996. Toward an integrative model of strategic international human resource management. Academy of Management Review, 21(4), 959985.

Teece, D. J. 1986. Profiting from technological innovation: Implications for integration, collaboration, licensing and public policy. Research Policy, 15(6), 285-305.

Tung, R., \& Punnett, B. J. 1993. Research in international human resource management. De Gruyter Studies in Organization, 35-55.

Turner, K. L., \& Makhija, M. V. 2006. The role of organizational controls in managing knowledge. Academy of Management Review, 31(1), 197-217.

Vaiman, V., Marshall, S., Napier, N. K., Taylor, S., Haslberger, A., \& Andersen, T. 2010. The end of a "period": Sustainability and the questioning attitude. Academy of Management Learning and Education, 9(3), 477-487.

Washburn, N. T., \& Hunsaker, T. B. 2011. Finding great ideas in emerging markets. Harvard Business Review, 89(9), 115-120.

Williamson, O. E. 1985. The economic institutions of capitalism: Firms, markets, relational contracting. New York: Free Press.

Winter, S. G., \& Szulanski, G. 2001. Replication as strategy. Organizational Science, 12(6), 730-743.

Wright, P. M., \& McMahan, G. C. 1992. Theoretical perspectives for strategic human resource management. Journal of Management, 18(2), 295-320. 
Wright, P. M., \& McMahan, G. C. 2011. Exploring human capital: putting 'human' back into strategic human resource management. Human Resource Management Journal, 21(2), 93-104.

Zellmer-Bruhn, M., \& Gibson, C. 2006. Multinational organization context: Implications for team learning and performance. Academy of Management Journal, 49(3), 501-518.

\section{Figure 1: Global Talent Portfolio}

\section{CORPORATE}

- Individual: Developed through firm-wide experience and/or directives.

- Unit: Generated inductively and deductively through social context of exchange/combination.

- Firm: Emerges as variation across business units is reduced to a common frame.

\section{High}

글

\section{SUBSIDIARY}

- Individual: Developed through personalized reconciliation of local and firm experience.

- Unit: Generated through aggregated exchange and combination of local and firm knowledge.

- Firm: Variety/heterogeneity across multiple units in the MNC.

\section{Low \\ INTERNATIONAL}

- Individual: Developed through experience or training of cross-border skills.

- Unit: Aggregated experience among members of the unit that generalizes across contexts.

- Firm: Common experience that provides global competitive parity with other firms.

\section{Location-Specificity \\ High}

\section{LOCAL}

- Individual: Developed through action and reflection in the local context.

- Unit: Generated through exchange and combination among members of the unit.

- Firm: Variety/heterogeneity among multiple units in the MNC. 
Figure 2: Multidomestic Strategy

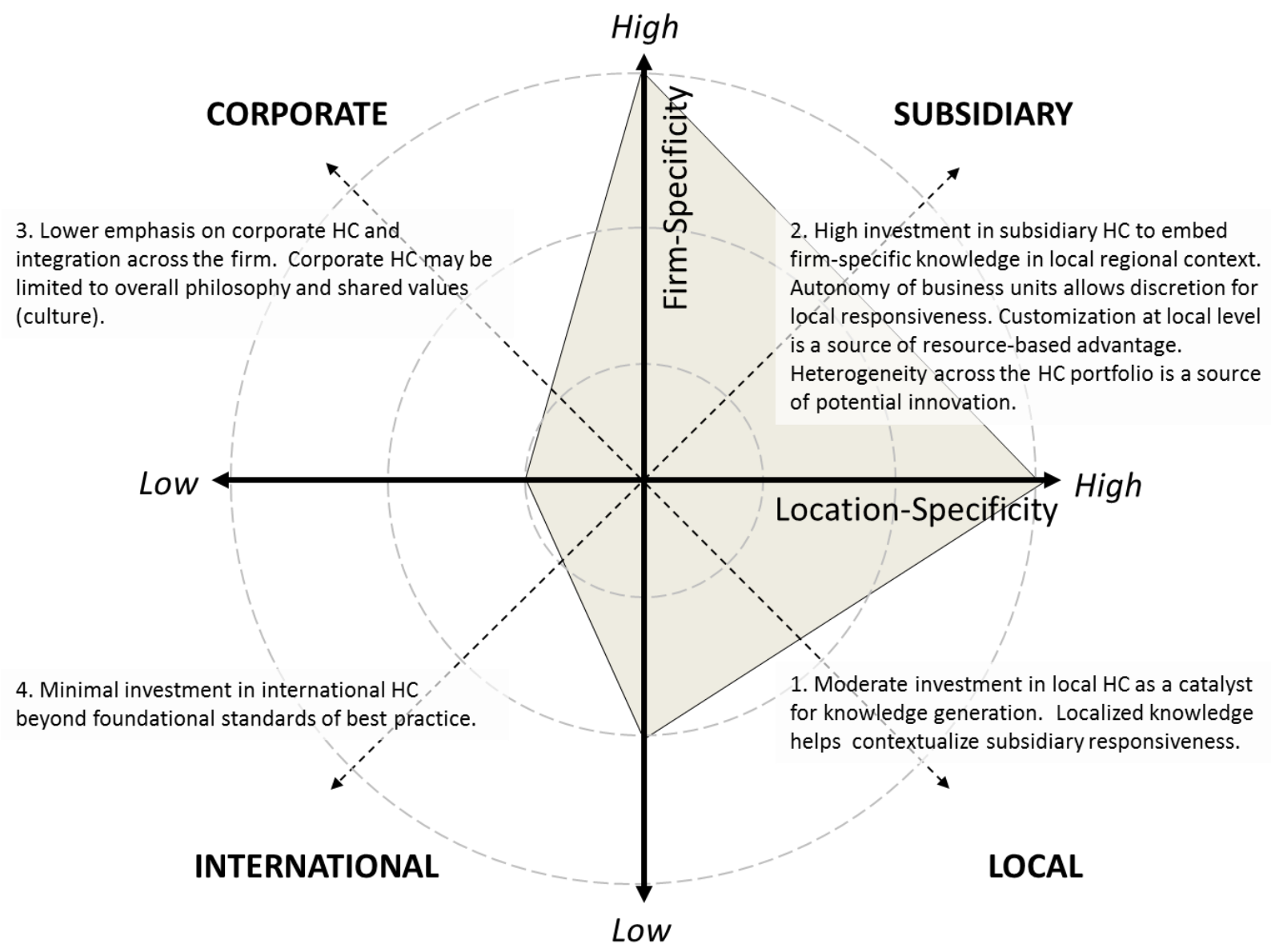




\section{Figure 3: Meganational Strategy}

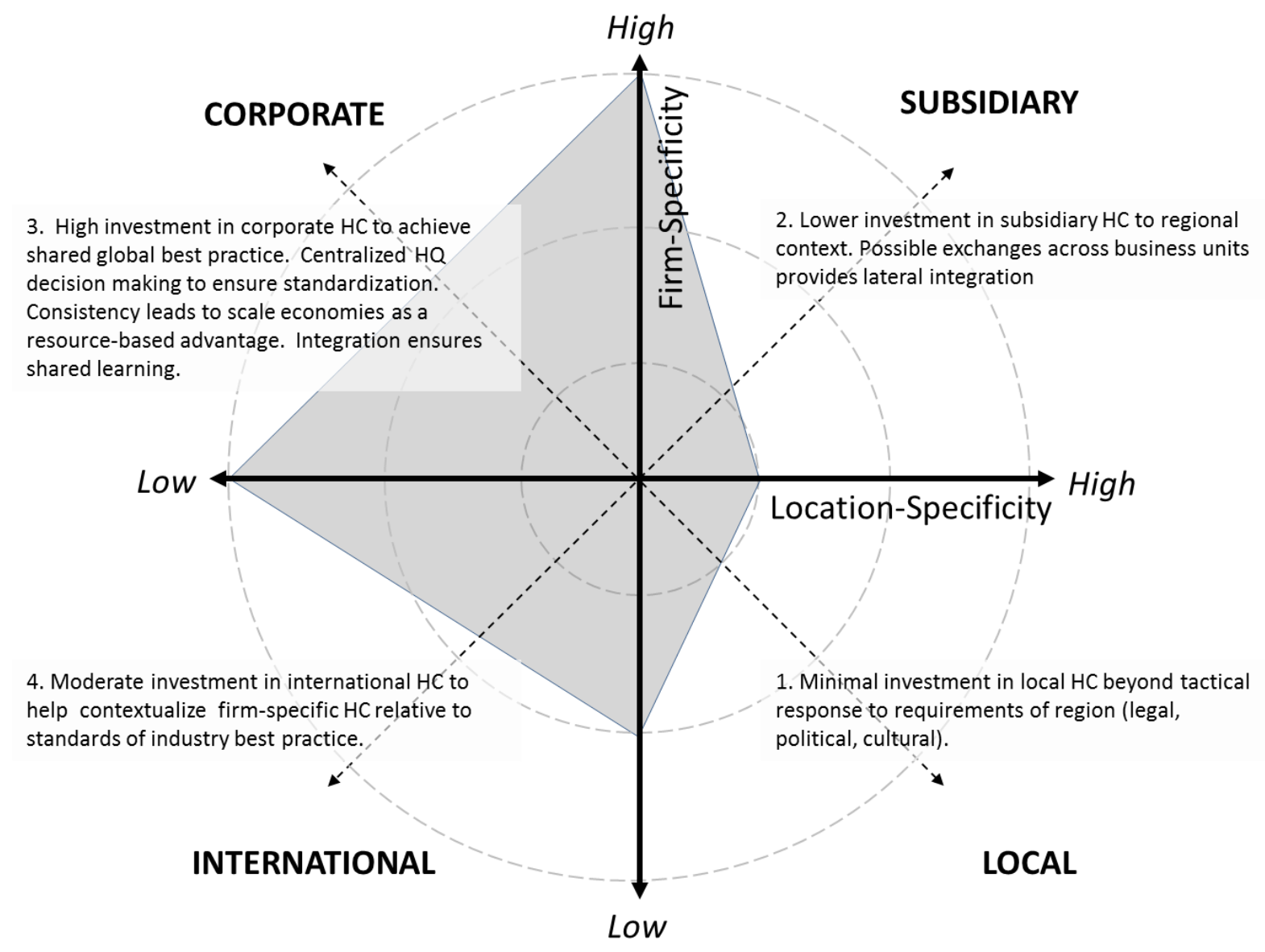




\section{Figure 4: Transnational Strategy}

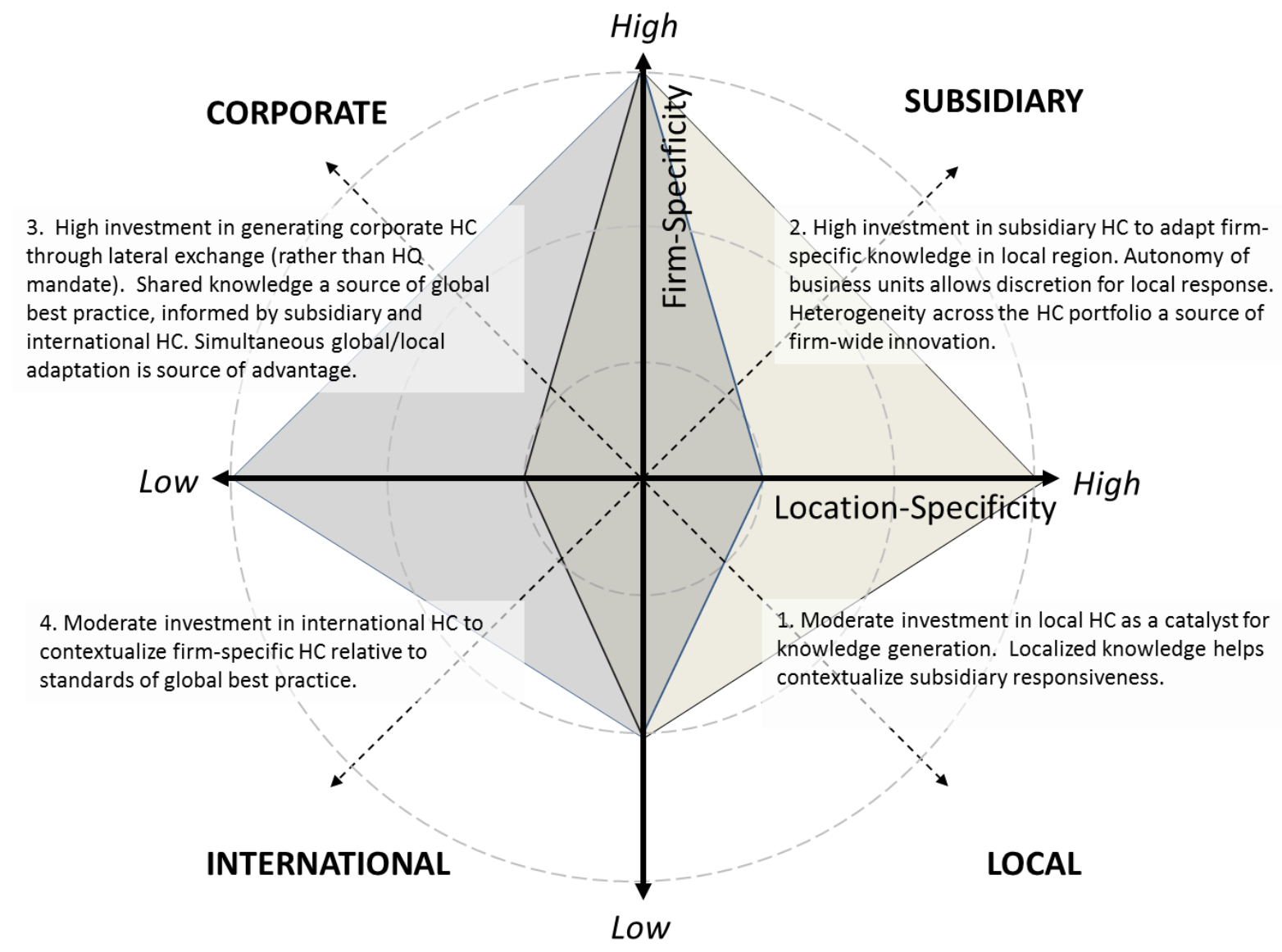




\section{Figure 5: Strategic HR Response}

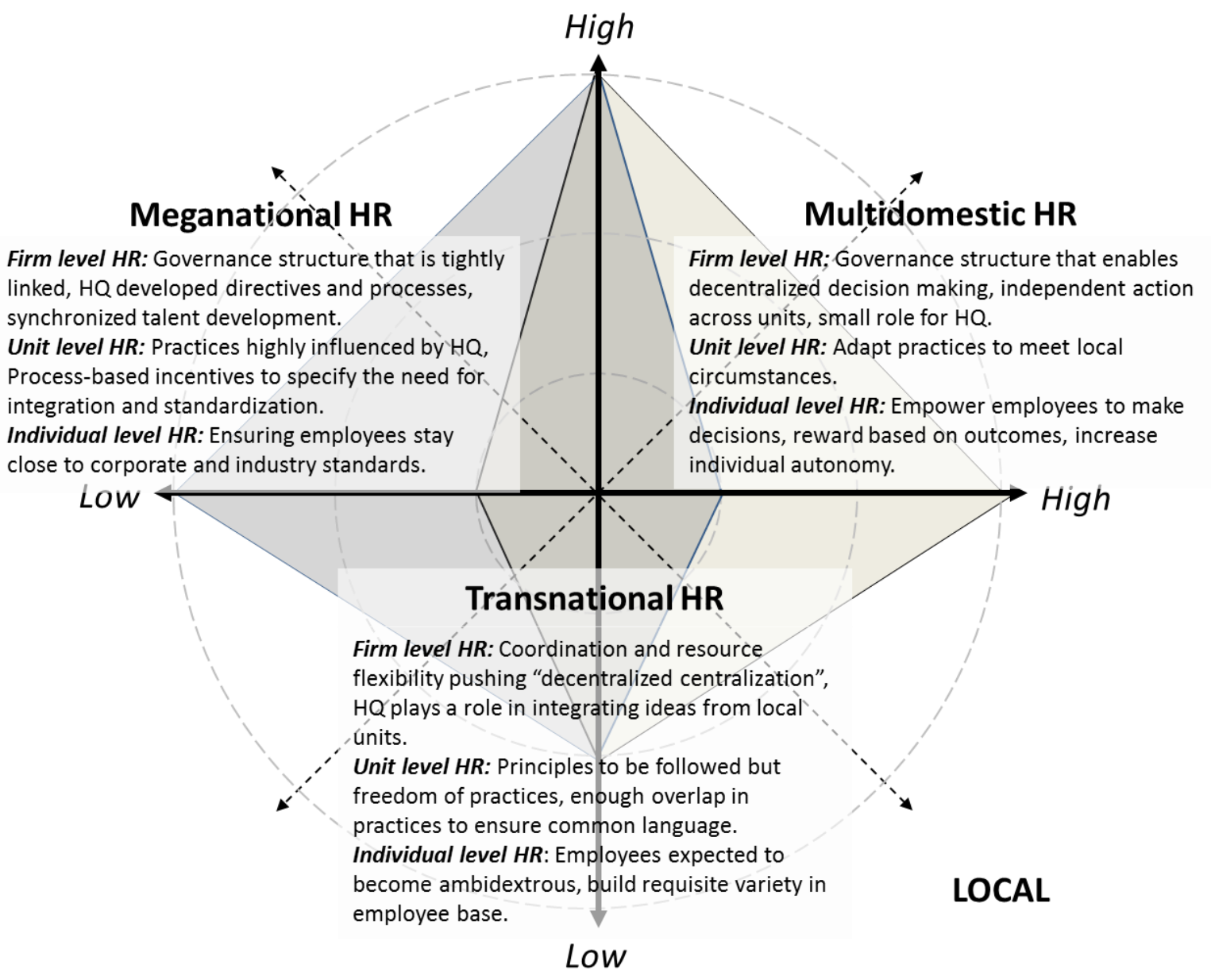


Figure 6: Aligning Levels of Human Capital with Strategy

\begin{tabular}{|l|l|l|l|}
\hline & Multidomestic & Meganational & Transnational \\
\hline Firm level & $\begin{array}{l}\text { Governance structure that } \\
\text { enables decentralized } \\
\text { decision making, } \\
\text { independent action across } \\
\text { units, small role for HQ }\end{array}$ & $\begin{array}{l}\text { Governance structure that is } \\
\text { tightly linked, HQ developed } \\
\text { directives and processes, } \\
\text { synchronized talent } \\
\text { development }\end{array}$ & $\begin{array}{l}\text { Governance structure that } \\
\text { encourages coordination } \\
\text { and resource flexibility; } \\
\text { pushing "dececentralized } \\
\text { centralization," HQ plays a } \\
\text { role in integrating ideas } \\
\text { from local units }\end{array}$ \\
\hline Unit Level & $\begin{array}{l}\text { Practices are adapted to } \\
\text { meet local circumstances }\end{array}$ & $\begin{array}{l}\text { Practices are highly } \\
\text { influenced by HQ, and } \\
\text { process-based incentives } \\
\text { are used to specify the need } \\
\text { for integration and } \\
\text { standardization }\end{array}$ & $\begin{array}{l}\text { Practices are governed by } \\
\text { principles, with a great deal } \\
\text { of freedom allowed and } \\
\text { enough overlap in practices } \\
\text { to ensure a common } \\
\text { language }\end{array}$ \\
\hline Individual Level & $\begin{array}{l}\text { Employees are empowered } \\
\text { to make decisions, are } \\
\text { rewarded based on } \\
\text { outcomes, and are given } \\
\text { increases in individual } \\
\text { autonomy }\end{array}$ & $\begin{array}{l}\text { Employees are directed to } \\
\text { stay close to corporate and } \\
\text { industry standards }\end{array}$ & $\begin{array}{l}\text { Employees are expected to } \\
\text { become ambidextrous and } \\
\text { to build requisite variety in } \\
\text { employee base }\end{array}$ \\
\hline
\end{tabular}

